NBER WORKING PAPER SERIES

ESTIMATES OF THE MAGNITUDE OF FINANCIAL AND TAX REPORTING CONFLICTS

\author{
George A. Plesko \\ Working Paper 13295 \\ http://www.nber.org/papers/w13295 \\ NATIONAL BUREAU OF ECONOMIC RESEARCH \\ 1050 Massachusetts Avenue \\ Cambridge, MA 02138 \\ August 2007
}

I have benefitted from comments and/or discussions with Jennifer Blouin, Michael Calegari, Raj Chetty, Peter Joos, Gil Manzon, Lil Mills, Tom Omer, John Phillips, Sonja Olhoft Rego, David Weisbach, Pete Wilson, and seminar participants at Boston College, Boston University, MIT, the University of Connecticut, the University of Illinois Tax Symposium, the Congress of the European Accounting Association, the Annual Meeting of the American Accounting Association, and the American Tax Policy Institute and National Bureau of Economic Research's 2006 Conferences on Financial Reporting and Taxation. This research was performed while I was on temporary assignment with the Internal Revenue Service. Particular thanks to Karen Cys, Ken Szeflinski, Nina Shumofsky, and Carol Miller of the Statistics of Income Division. Research support was generously provided by the American Tax Policy Institute in conjunction with the Conference on the Intersection of Financial Accounting and Tax Policy. The views expressed in this paper are mine alone and do not necessarily reflect the views of the National Bureau of Economic Research.

(C) 2007 by George A. Plesko. All rights reserved. Short sections of text, not to exceed two paragraphs, may be quoted without explicit permission provided that full credit, including $\odot$ notice, is given to the source. 
Estimates of the Magnitude of Financial and Tax Reporting Conflicts

George A. Plesko

NBER Working Paper No. 13295

August 2007

JEL No. C50,H25,M41

\begin{abstract}
$\underline{\text { ABSTRACT }}$
This study examines the tax reporting consequences of financial reporting discretion. Using a matched sample of financial statements with tax returns, I provide estimates of the accuracy of tax return information inferred from financial statements. To examine the tradeoffs between financial and tax reporting, I model the relation discretionary financial accounting accruals have to discretionary federal tax accruals. The methodology takes advantage of the contemporaneous nature of reporting to mitigate econometric problems identified in previous research. I find the extent tax reporting reflects discretionary financial reporting varies dramatically by industry, profitability, and the sign of discretionary accruals. I also find managers are able to undertake tax reducing activities with less of an effect on financial reporting than tax increasing accruals, consistent with recent evidence on the differential growth of book and tax income, and with tax avoidance activities.
\end{abstract}

George A. Plesko

Department of Accounting

University of Connecticut School of Business

2100 Hillside Road, Unit 1041A

Storrs, CT 06269-1041

gplesko@uconn.edu 


\section{Estimates of the Magnitude of Financial and Tax Reporting Conflicts}

\section{Introduction}

Companies face inherently conflicting interests in their reporting for financial and tax purposes. While higher financial reporting earnings are generally viewed as favorable, higher taxable income can result in additional tax liabilities. Although differences in the amounts of income reported under each system have existed since the inception of the corporate income tax (Smith and Butters, 1949), over the past decade an increasing disparity has developed between both the levels, and growth rates, of each income measure. In an analysis of the tax returns of large corporations, the U.S. Treasury (1999) reported income for financial and tax accounting purposes diverged sharply during the latter part of the 1990s, a pattern also found in analyses of publicly-available data by Plesko (2000b), Manzon and Plesko (2002), and Desai (2003), and in comparisons of national income account data with tax collections (Sullivan 1999). Plesko and Shumofsky (2004) document that aggregate pretax book income reported by U.S. corporations on their 1995 tax returns was 22 percent higher than its tax accounting equivalent - a difference that increased to more than 59 percent in 1999, approximately \$318 billion in the aggregate. This divergence in the amount of income reported under each system has been offered as prima facie evidence of increases in tax avoidance activities of firms and of a deterioration in the efficacy of the tax system. ${ }^{1}$ Increasing book tax differences, coupled with concerns about corporate tax compliance generally, have also prompted hearing by the Senate Finance Committee which included a discussion on the merits of requiring the disclosure of corporations'

\footnotetext{
${ }^{1}$ See, generally, Bankman (1999, 2003), Schler (2002), Talisman (2000), Weisbach (2002), and Yin (2001).
} 
tax return information to improve the public's knowledge of firms' tax positions. Such an argument is implicitly predicated on the assumption that the tax information that would be useful to the public cannot be inferred from the published financial statements. ${ }^{2}$

This study empirically addresses the extent of the tradeoffs between financial and tax reporting in an earnings management setting. I begin by analyzing the ability of tax information inferred from financial statements to accurately characterize both the tax position and tax return values. Then, utilizing a standard model of discretionary accruals, I estimate the extent the tax reporting system reflects discretionary financial reporting decisions. Differences in accounting rules will yield differences in both the levels, and patterns, of accruals under each reporting system, even though each is driven by the same underlying economic activities. I employ an empirical approach to exploit these differences to obtain more precise estimates of discretionary accruals, mitigating concerns over omitted variables and mis-specification in accruals models. Further, the correlation of the estimated discretionary accruals from each system provides a measure of the extent to which discretionary actions in one system, such as those taken to increase financial reporting income, is reflected in the accruals of the other.

The intuitive motivation for this paper is as follows. If tax and financial reporting were based on identical rules, any change in income or expense under one system would be perfectly reflected in the other. Under identical rules, tax reports could not escape being affected by financial reporting-motivated activities and financial accounting choices would have immediate tax consequences. At the other extreme, if tax and financial measures of income were unrelated (e.g., both random draws from some underlying distribution) then tax accounting income

\footnotetext{
${ }^{2}$ See Grassley (2006) for an overview of the hearing and Kleinbard (2006) for a discussion of the merits of partial disclosure of the corporate income tax return.
} 
measures would not be affected by the financial reporting amounts. Any action taken to change reported book income would not be contemporaneously reflected in the firm's tax accounts, and would yield no tax reporting cost. ${ }^{3}$

In practice, and design, the U.S. tax system falls between these two extremes. Although both accounting systems report income measures derived from the same underlying economic transactions, the patterns, and magnitudes, of income and expenses recognized under each system vary. Some aspects of reporting may be identical under both (e.g., cash sales with no right of return), while others are disparate (e.g., non-qualified stock options). This latter category is inclusive of numerous transactions that have generated concern over companies’ abilities to greatly reduce tax liabilities without any financial reporting consequences.

I find that many important corporate tax attributes cannot be inferred from publiclyavailable financial reporting information, a result that potentially supports arguments for greater public disclosure of tax information by firms. With respect to firms' ability to differentially report income to tax authorities and in financial reports, I find the degree to which tax reporting reflects discretionary financial reporting decisions varies significantly by industry, profitability, and by the sign of discretionary accruals. These results imply that some managers are able to recognize significant financial reporting income without tax consequences and undertake substantial tax reducing activities without being subject to financial reporting costs. Both of these results are consistent with recent evidence on the differential growth of book and tax income and with tax sheltering activities.

The paper also provides two methodological contributions. First, it demonstrates the

\footnotetext{
${ }^{3}$ Deferred tax accounting is ignored for the sake of this example. So long as a system based upon random draws treated all differences as permanent the example would still hold.
} 
efficacy of an alternative approach to the estimation of accruals models that utilizes tax information to obtain better estimates of nondiscretionary accruals. Second, the industry level estimates provided in the paper can be used in future empirical studies to provide cross-sectional controls for the extent of book-tax conformity, similar to country controls utilized in international comparisons.

The next section of the paper describes prior research on the tension between financial and tax reporting. The third section presents the methodology of the paper, followed in the fourth section by a description of the data and the construction of the sample. Section five presents an analysis of the matched tax return to financial statement data, and tests the ability of tax information inferred from financial statements to assess tax characteristics. The estimation results for the model are provided in section six presents, along with a discussion of both aggregate and industry-level results, and a comparison of estimation results using different datasets and specifications. The final section presents the conclusions.

\section{Prior research}

The tension between financial reporting and other firm objectives is a common research theme in accounting choice generally (Fields et al. 2001) and in tax (Shackelford and Shevlin 2001, Maydew, 2001). In examining the financial-tax reporting tradeoff specifically, the empirical literature has been inconsistent in its assumptions regarding the linkage of the two, and studies have made conflicting assumptions. ${ }^{4}$ For example, in examining the effects of various

\footnotetext{
${ }^{4}$ Certain transactions have transparent effects that appear to influence behavior, such as inventory methods (e.g. Hunt et al. 1996), the management of stock options (Matsunaga et al. 1992) and financing methods (Engel et al. 1999). Shackelford and Shevlin (2002), Maydew (2002) and Scholes, et al. (2002) chapter 6, all discuss the importance of non-tax considerations in the tax planning process.
} 
aspects of the Tax Reform Act of 1986, Scholes, Wilson, and Wolfson (1992) test whether firms deferred income to take advantage of declining tax rates, assuming such deferrals are reflected in taxable income in each period. By contrast, the earnings management literature surrounding the adoption of the book income preference of the corporate alternative minimum tax (Gramlich 1991, Boynton et al. 1992, Manzon 1992) assumes reductions in book income were generally independent of the amount of contemporaneous taxable income, since only asymmetric reductions would reduce the book-tax difference of a firm.

In an attempt to directly measure the link between accounting choices, Erickson et al. (2002) analyzed a small sample of firms subject to SEC action for overstating revenue. They conclude these firms concurrently increased reported taxable income, with firms apparently willing to pay approximately 11 cents in tax per each dollar of overstated earnings, based on revisions to the tax expense. There is no indication these results can be generalized beyond their small and unique sample, given these firms not only aggressively overstated earnings but did so in a way so as to attract regulatory scrutiny. Further, given their reliance on the tax expense, they cannot quantify the extent to which additional taxes were actually paid beyond some disclosures of expected tax refunds. Nonetheless, that firms found it necessary to pay additional taxes implies that not all changes in reported book income can be made independent of taxable income.

Other evidence of potential costs is found in Mills (1998), who reports firms with greater book-tax differences are subject to greater scrutiny by the IRS and to greater proposed adjustments in their returns. The full extent of the cost of differential reporting cannot be inferred from her results since the ultimate resolution of the adjustments was not observed and 
the final change in taxes paid being only a small percentage of such adjustments. However, her results demonstrate that larger book tax differences will draw the attention of tax authorities to the extent that they are observable in the tax return, and therefore a divergence between reported book and taxable income may impose additional tax costs on the firm. Potentially reducing this cost, Mills and Plesko (2003) document significant shortcomings in the reporting of book income for tax purposes, leaving open the possibility that many reporting differences remain unreported to, and undetected by, tax authorities.

Even if explicit tax sheltering is not the goal other accounting practices, such as the treatment of non-qualified stock options, have caused substantial differences in the amount of income reported for financial and tax purposes - differences not necessarily reflected in the tax accounts of a company’s financial reports and supported by recent analyses of aggregate financial and tax return data. $\quad$ In addition to these accounting differences, methodological concerns have been raised over the empirical approaches used to test for tax and non-tax costs (Shackelford and Shevlin, 2001).

\section{Methodology}

To examine the reporting relation between the two accounting systems I focus on differences in accruals under each as the amount of cash collected by a company in any given period is independent of the accounting method.

\footnotetext{
${ }^{5}$ Hanlon and Shevlin (2000) and Manzon and Plesko (2001) both discuss the accounting treatment of stock options and their distortionary effects on the tax accounts of financial statements. Boynton et al. (2004), Plesko (2002, 2003), and Plesko and Shumofsky (2004) present tax-return tabulations on identifiable sources of book-tax differences.
} 
Pretax financial reporting total accruals for company $i$ in period $t\left(T A_{i, t}^{F}\right)$ can be written

as:

$$
T A_{i, t}^{F}=R B I_{i, t}-C F_{i, t}
$$

where $R B I_{i, t}$ is pretax reported book income and $C F_{i, t}$ is the firm's pretax cash flow.

Similarly, tax reporting total accruals for company $i$ in period $t$ can be defined as:

$$
T A_{i, t}^{T}=T I_{i, t}-C F_{i, t}
$$

where $T I_{i, t}$ equals reported taxable income. Assuming cash flows are the same under each

accounting system, tax accruals will differ from pretax book accruals to the extent pretax book income differs from taxable income, that is

$$
T A_{i, t}^{F}-T A_{i, t}^{T}=R B I_{i, t}-T I_{i, t}
$$

As a result, tax accounting accruals can be estimated from financial accounting accruals if one knows the difference between reported book and taxable income. Such differences will depend on both timing differences (such as the differences in depreciation patterns) and scope (such as the inclusion or exclusion of unrepatriated foreign income). ${ }^{6}$

Following McNichols and Wilson (1988) total accruals under each accounting system

\footnotetext{
6“Tax accounting accruals” is a bit of a misnomer in that firms are not as easily able to affect taxable income through non-cash means. However, actions a firm might engage in to manipulate taxable income without affecting book income would exploit the differential treatment of a transaction by the accounting systems. For example, repatriating foreign earnings will not affect the total amount of pre-tax cash a firm has, but will increase tax net income without affecting pretax book income.
} 
can be decomposed into their non-discretionary (NDA) and discretionary (DA) components:

$$
\begin{aligned}
& T A_{i, t}^{F}=N D A_{i, t}^{F}+D A_{i, t}^{F} \\
& T A_{i, t}^{T}=N D A_{i, t}^{T}+D A_{i, t}^{T}
\end{aligned}
$$

where the estimate of $N D A_{i}$ is defined as the predicted value from an accruals equation, and $D A_{i}$ is defined as the equation's residual.

The specification and estimation of accruals models has been the subject of significant discussion, with critical reviews of earnings management methodologies performed by Dechow et al. (1995), Thomas and Zhang (1999), McNichols (2000), Fields (2001), and Kothari (2001). Thomas and Zhang (1999) compare a number of empirical approaches to estimating accruals models, inclusive of the specifications tested by Dechow et al. (1995). While they conclude none of the models are particularly strong, an industry level version of the Jones (1991) model was found to outperform the original Jones (1991) model. As a result, a modification of the Jones (1991) specification is used to estimate financial accruals:

$$
\frac{T A_{i, t}^{F}}{A_{i, t-1}}=\alpha_{F 0}+\alpha_{F 1} \frac{1}{A_{i, t-1}}+\beta_{F} \frac{\Delta \text { Sales }_{i, t-(t-1)}}{A_{i, t-1}}+\gamma_{F} \frac{P P E_{i, t}}{A_{t-1}}+\rho_{F} \frac{T A_{i, t-1}^{F}}{A_{i, t-2}}
$$

where $\Delta$ Sales is the change in sales from the past year (adjusted for changes in accounts receivables) , $P P E$ is gross property, plant, and equipment, and $A_{t-1}$ is prior year total assets. A lag of total accruals is included to capture mean reversion. For tax accruals, the empirical 
model is specified as

$$
\frac{T A_{i, t}^{T}}{A_{i, t-1}}=\alpha_{T 0}+\alpha_{T 1} \frac{1}{A_{i, t-1}}+\beta_{T} \frac{\Delta \text { GrossReceipts }_{i, t}}{A_{i, t-1}}+\gamma_{T} \frac{P P E_{i, t}}{A_{i, t-1}}+\rho_{T} \frac{T A_{i, t-1}^{T}}{A_{i, t-2}}
$$

with the explanatory variables the same as those used in equation (6) with the exception of $\Delta$ Gross Receipts, which is the tax accounting equivalent of sales. The predicted values from these models are taken as estimates of nondiscretionary accruals, and the residuals as estimates of discretionary accruals (DA).

An important concern highlighted in the reviews of empirical accruals models has been the extent to which the estimation of total accruals equations, such as (6) and (7), using ordinary least squares (OLS) are affected by omitted variables and the simultaneity of the explanatory variables with the methods available to manage earnings. ${ }^{7}$ In this setting, pretax total accruals under each accounting system are driven by the same underlying economic activity of the firm. Assuming total accruals are determined contemporaneously, rather than simultaneously, an econometrically efficient approach is to jointly estimate the two equations using a system of seemingly unrelated regressions. ${ }^{8}$ In such a setting, cross-correlations and the omitted variables affecting each equation will be captured in the covariance matrix, and the independence of the errors across the two equations can be explicitly tested. Further, unlike the residuals from OLS, the residuals from FGLS will not be jointly correlated with the omitted variables affecting both

\footnotetext{
${ }^{7}$ Kang and Sivaramakrishnan (1995), in particular, propose an instrumental variables approach to address these issues. McNichols (1999) suggests that additional variables be included to control for long-term growth.

${ }^{8}$ Greene (1997) discusses Zellner's method of estimating a feasible generalized least squares regression (FGLS) of seemingly unrelated regressions.
} 
equations, eliminating any induced correlation of concern to previous authors. Finally, any correlated regularity in the two different accruals processes will lead to more efficient estimates of the parameters. Thus, the use of FGLS residuals in place of OLS residuals addresses the same set of econometric issues as Kang and Sivaramakrishnan (1995), but potentially provides an easier to implement alternative to both their instrumental variables approach, and the need to search for additional covariates to include in Jones’ (1991) based models. ${ }^{9}$

After obtaining estimates of discretionary accruals from the joint estimation of (6) and (7) the relation between discretionary accruals across the two accounting systems can be estimated as

The coefficient $\phi$ will capture mean differences in accruals across the two systems and $\omega$

$$
\frac{D \hat{A}_{i}^{T}}{A_{i, t-1}}=\phi+\omega \frac{D \hat{A}_{i}^{F}}{A_{i, t-1}}
$$

provides an estimate of the amount by which estimated discretionary accruals for financial reporting are contemporaneously related to discretionary accruals related to taxable income. If $\omega=0$, discretionary tax accruals are unrelated to discretionary financial accruals. If $\omega \neq 0$, the magnitude of the coefficient will capture the change in the tax accrual associated with a change in pretax book accruals, and provide a measure of the extent of tax reporting costs associated with earnings management.

Additional covariates can be added to equation (8) to test for difference due to other characteristics. In order to test for asymmetry in the effects of the sign of discretionary accruals

\footnotetext{
${ }^{9}$ Calegari (2000) estimates the effect of capital structure changes on discretionary accruals through the use of a simultaneous-equation approach. However, to derive his estimates of discretionary accruals he estimates his total accruals equations using OLS, implicitly assuming that OLS is applicable.
} 
and of the tax status of the firm the equation is specified as:

$$
\frac{D \hat{A}_{i}^{T}}{A_{i, t-1}}=\alpha_{0}+\alpha_{1}+\beta_{1}\left(\frac{D \hat{A}_{i}^{F}}{A_{i, t-1}}>0\right)+\beta_{2}\left(\frac{D \hat{A}_{i}^{F}}{A_{i, t-1}}<0\right)+\gamma_{1}\left(\frac{D \hat{A}_{i}^{F}}{A_{i, t-1}}>0 * N E G T I\right)+\gamma_{2}\left(\frac{D \hat{A}_{i}^{F}}{A_{i, t-1}}<0 * N E G T I\right)
$$

where the explanatory discretionary accruals variable is split into two separate variable depending on the sign of $D A$, and two additional variables are created by multiplying each $D A$ variable by a binary variable equal to one if the firm has negative tax net income in the current year. The addition of an interaction for negative tax net income allows for testing whether discretionary accruals are affected by the current period's tax cost (or benefit) of a change in reported taxable income.

\section{Data}

I use a matched sample of firms' financial statement and tax return data for tax years 1994 to 2001 . The advantage of the data used in this paper is the ability to observe actual reported taxable income rather than an estimate based on financial reporting. To construct the sample, I begin with the Internal Revenue Service’s Statistics of Income's (SOI) annual corporation file, containing tax return information for more than 80,000 corporations. ${ }^{10}$ Tax return data are recorded as filed, and validated for accuracy, but do not reflect any subsequent amendments or audit adjustments. Firms filing 1120-A, the corporate short form, as well as passthrough entities, such as subchapter S corporations, REITs, and RICs ,were dropped.

\footnotetext{
${ }^{10} \mathrm{~A}$ description of the IRS sample and sampling methodology can be found in U.S. Internal Revenue Service (2004).
} 
Financial statement information was drawn from Compustat ${ }^{11}$ and matched to the tax return data by employer identification number. Non-matched firms were deleted, as were firms with missing or zero assets, yielding 43,320 firm-year observations. Of this group, 37,853 had sufficient financial statement data to allow a simple comparison to the matched tax return. Summary statistics for this set of firms are provided in Table 1, Column (A).

To reduce the effects of consolidation, and focus solely on accounting differences, the value of total assets on the tax return balance sheet was compared to that reported in the financial statement. The balance sheet of the tax return (Schedule L) should reflect the assets and liabilities of the tax filing entity, regardless of GAAP consolidation. ${ }^{12}$ If the difference between the two values exceeded 0.01 of the smaller value the record was deleted, reducing the sample to 17,617 firm-years. Summary statistics for these firms are reported in Table 1, Column ( C). The estimation of equations (6) and (7) requires the imposition of additional restrictions on the sample, yielding a final sample of 6,062 firm-year observations for 1996 to 2001. Observations for 1994 and 1995 were lost owing to the need to have lagged values in the construction of the regression variables and the presence of a lagged dependent variable in the regression.

The tax return contains two different measures of income. Tax net income (LINE28) is

\footnotetext{
${ }^{11}$ Scaled pretax total accruals were calculated as pretax book income (data123+data16) less cash flows from operations adjusted for deferred taxes (data308-data126). Other Compustat variables used in the regressions are assets (6), the change in sales (data 12) adjusted for the change in accounts receivables (data302), and gross property plant and equipment (7).

${ }^{12}$ See Dworin (1985), Manzon and Plesko (2002), Mills (1998), Hanlon (2003), Plesko (2003), Mills and Plesko (2003), and Boynton et al. (2004) for discussions of consolidation issues. The effect of imposing a consolidation rule should be to bias the estimation towards finding close links between the two systems. With more complicated firms, particularly those with multiple tax and financial entities, the ability of either set of data to capture changes in the other will be reduced.
} 
conceptually equivalent to pretax book income; income subject to tax (IST) is determined after the deduction for net operating losses and dividends received, but, unlike LINE28, is constrained to be nonnegative for purposes of calculating tax liability. I modify LINE28 by subtracting special deductions (dividends received and net operating losses) to obtain a measure of taxable income that can be negative. ${ }^{13}$

Because tax return information is not publicly available, I include estimates of tax liability (data 63, Current Tax Expense) and taxable income, GROss63, defined as the grossed-up amount of data 63, plus the change in net operating loss carryforwards (item 52) and test its ability to proxy for tax return information. ${ }^{14}$

Given the unique nature of the data, the next section presents an analysis of the matched sample of tax and financial statement data, and is followed by a discussion of the results of the estimation of the accruals models.

5. The financial statement as a source of tax information

The summary statistics provided in Table 1 allow for a test of an essential question of interest to a broad group of financial statement users: how well does the financial statement represent the tax characteristics of a firm? For the sample of 37,853 matched firms, Column (B) of Table 1 provides the results of a t-test for the hypothesis that the difference in the two series

\footnotetext{
${ }^{13}$ Arguably, any change in IST as defined in the tax code will be the result of a change in tax net income. However, the opposite need not be true as any decrease in net income for a company with negative net income would not affect IST, and an increase in net income would only change IST if it were large enough to make it positive. The modified definition allows for the possibility that firms could increase the amount of income reported to the IRS without affecting their taxable income.

${ }^{14}$ Plesko (2000a, 2003) discusses the limits of financial statement information to capture different attributes of the tax return and the efficacy of alternative financial statement constructs. Mills, et al. (2003) evaluate the ability of Compustat to capture the correct amount of net operating loss carryforwards.
} 
(book minus tax) is statistically different from zero. The first cell in Column (B) reports that the test of whether book assets less tax assets is equal to zero cannot be accepted $(t=-9.67)$. While this result is not surprising given the issues of consolidation discussed earlier, it is surprising that mean assets reported on the tax return are greater than those reported on financial statements. ${ }^{15}$

The next cell presents the results of the same test between reported receipts, and again rejects that their difference is zero. Mean sales reported on financial statements are more than 10 percent larger than those reported on the tax return.

The third cell in Column (B) shows the comparison of the amount of book income reported to shareholders and the amount reported to tax authorities on the Schedule M-1. In contrast to the asset and gross receipts results, the values for pretax book income are not statistically different from each other $(\mathrm{t}=0.71)$. The next two cells report a similar result in comparisons of the financial statement estimate of taxable income, GROsss63, to both Tax Net Income and Income Subject to Tax - in neither case can the hypothesis be rejected. While these results suggest that, in large samples, the financial statement provides informative data regarding firms' taxable income, this finding is puzzling, given that both assets and revenues are statistically different. Further, while grossing-up the current tax expense appears to approximate taxable income, the current tax expense does not provide a statistically reliable estimate of firms' actual tax liability, either before or after credits. The mean of the current tax expense (18.23) falls between the reported amount of tax before credits (20.16) and tax after credits (14.88), and t-tests reject the hypotheses that the difference between the book amount and

\footnotetext{
${ }^{15}$ While surprising, this result is not anomalous, and has been previously reported by Mills et al. (2002) and Manzon and Plesko (2007). Boynton et al. (2004) provide a detailed examination of consolidation differences for tax and financial reporting and the effects on the interpretation of reported book-tax reporting differences.
} 
the tax amounts are zero.

Column (D) reports the analysis for the sample of 17,617 firm-year observations retained because of the similarity in reported assets. The smaller sample size - more than half of the observations in Column (A) are dropped - highlights the difficulty in making proper inferences about firms' tax attributes from publicly available data, since the reporting entities are generally different. While the mean amount of revenues are statistically equivalent $(\mathrm{t}=0.81)$, the average amount of pre-tax book income reported to shareholders is statistically greater than the amount reported on the tax return $(\mathrm{t}=3.47)$. Similarly, the amount of taxable income inferred from the financial statements is statistically greater than either reported tax net income $(t=13.83)$ or income subject to tax $(\mathrm{t}=6.63)$, suggesting that inferences of taxable income systematically overstate the actual amount of taxable income for similarly consolidated entities. Worth noting here is that income subject to tax is larger than tax net income since tax net income can be negative while income subject is bounded below by zero. This pattern continues into the estimates of actual tax liability, either before or after credits, with the average amount inferred from financial statements statistically greater than actual tax before, or after, credits $(\mathrm{t}=2.71$ and 6.45, respectively).

Finally, Column (F) provides a similar analysis for the smaller sample of 6,062 firm-year observations retained because of the similarity in reported assets and the availability of data to be used in testing the central questions of this paper. The results for this sample are similar to those reported in Column (D), with only gross receipts reported under the two systems not statistically different from each other $(\mathrm{t}=0.38)$. Book income reported to shareholders is greater than reported on the tax return's Schedule M-1 ( $\mathrm{t}=1.87)$, as is estimated taxable income (GROSSS63 is 
statistically larger than both tax net income $(\mathrm{t}=9.84)$ and income subject to tax $(\mathrm{t}=6.00))$. The values of tax liability, either before or after credits, are both smaller than the amount reported as the current tax expense, and each is statistically different from the value inferred from the financial statements.

Tables 2 and 3 provide further evidence on the efficacy of inferring the tax attributes of firms from financial statements by comparing the signs, rather than the levels, of taxable income and tax liabilities. Table 2, for each of the three samples, presents a cross tabulation of the sign of tax net income (LINE28) with the sign of taxable income that is inferred from the financial statements. Arguably, similarity in the signs of these variables is a lower standard than the equivalence in magnitude, but a firm's current tax position is an important determinant of behavior. The results are similar for all three comparisons: between 12 and 13 percent of firms in the sample are mis-classified, and in all cases the majority of the mis-classifications using financial statement information imply that a firm has taxable income when, based on the tax return, it does not. The greatest imbalances in mis-classification occur in the two cases where conditions have been imposed to ensure that the entities are the most similar, with more than twice as many firms incorrectly classified as taxable than mis-classified as non-taxable.

Table 3 repeats the comparisons of Table 2, but focuses on whether the sign of firms' tax liability (either before or after credits) is correctly inferred from the financial statements. This additional comparison is necessary because a firm may have no liability even when taxable income is positive (primarily because of credits), or because a tax liability may exist even when taxable income is zero (owing, for example, to non-income, recapture, or the minimum tax). The pattern of mis-classification for a current tax expense is the similar to that reported in Table 
2: mis-classifications in each of the six cases primarily label firms as taxable when they are not. The mis-classification is less pronounced in tax after credits than tax before credits, but remains above 10 percent in each of the three samples.

The data presented in Tables 1 through 3 provide strong evidence that financial statement information yields misleading inferences about firms' tax attributes. These results, encompassing many more years and observations than previous research, are consistent with prior conceptual (Hanlon, 2003, Mills and Plesko 2003) and empirical (Dworin, 1985, Plesko 2001, Mills et al. 2002, McGill and Outslay, 2004) analyses. At a minimum, these results suggest that financial statement-based tax inferences must be interpreted and used with caution. With respect to th current policy debate over the magnitude, and trend, of book-tax differences, the results of Tables 1 through 3 show that measures constructed from financial statements will understate the magnitude of reporting differences. The extent to which financial statement constructs may adversely affect the results of empirical research is addressed in the next section.

6. Model estimation

A. General results

Estimation of the accrual models requires additional financial statement information from each firm and the imposition of constraints on the data, leading to a final sample of 6,062 firmyear observations. While some of this data has been described in Column (E) of Table 1 and further in Tables 2 and 3, summary statistics for the additional variables are presented in Table 4, Panel A. To obtain total accruals under tax accounting the difference between pretax book and taxable income was subtracted from book total accruals. For tax accruals based on 
Compustat item 63, GROss63, the difference between estimated taxable income and book income was subtracted from book total accruals.

Panel B of Table 4 provides the correlations between pretax book income (Compustat data item 170), tax net income (LINE28) and GROSS63, the financial statement estimate of taxable income. The first column provides the correlations between pretax book income and the two measures of taxable income. While the equality of means between these variables was rejected in Table 1, Panel B shows that all of the correlations are statistically significant at one percent. The correlation for GROSS63 is higher than for modified taxable income (line 28), with correlations of 0.78 and 0.70 , respectively, a non-surprising result since GROSs63 and pretax book income are drawn from the same financial statement. The second column of the panel shows that the correlation between tax net income and GROSs63, the financial statement measure of the same item is 0.67 . The third panel of Table 4 provides the correlations of scaled total accruals for each definition. Of the two tax income accruals, GROSss63 is more highly correlated with pretax book income accruals - again not a surprising result given that both are drawn from the same financial statements.

Table 5 provides a description of the industry distribution of the sample along with the correlations of the residuals from jointly estimating equations (6) and (7). ${ }^{16}$ Two sets of systems of equations are estimated: System 1 utilizes tax return information to measure the effects on tax reporting while System 2 substitutes tax return information inferred from financial statements. While it is usual for both regulated industries and financial services to be omitted from accruals models, I include both as benchmarks. Regulated industries are often excluded because the

\footnotetext{
${ }^{16}$ Coefficient estimates from the accruals equations have been omitted in the interest of space.
} 
nature of the regulatory process makes them less interesting to study. In this setting, however, regulated industries should have relatively high correlations, and their inclusion allows for this hypothesis to be examined. Similarly, while the Jones (1992) model is viewed as less representative for non-manufacturing industries, the applicability of the model can be directly tested. Further, any mis-specification due to omitted variables in the accruals model will be mitigated through the use of FGLS.

The correlation of the residuals from the first-stage OLS regression provides information on whether the assumptions of the OLS model are violated and an improvement can be made via joint estimation. A Breusch-Pagan test of the independence of each set of residuals was performed for each set of equations, and independence of the residuals can be rejected in all but one case (Public Administration for GROss63), confirming the appropriateness of the FGLS approach over OLS with either set of data. ${ }^{17}$ For the remaining tests, the residuals from the FGLS estimates are used as estimates of discretionary accruals, where BOOKDA represents discretionary book accruals, and LINE28DA and GROSS63DA represent taxable income accruals estimated, respectively, using tax return or financial statement information.

Table 6 provides the Pearson correlation coefficients of the FGLS discretionary accruals estimated at the industry level, and then pooled. Coefficients in bold were estimated within the same system of equations. Within the first system, which uses tax return information, the correlation of financial and tax discretionary accruals is 0.472 and statistically significant. GROss63, however, yields a much lower correlation (0.071) within the sample. The estimates of BOOKDA across the two systems are highly correlated (0.993), and LINE28DA is nearly equally

\footnotetext{
${ }^{17}$ Here and throughout the rest of the text, accepting or rejecting statistical tests are relative to a 1 percent significance level.
} 
correlated with BOOKDA in each model (0.472 and 0.466). Of note, the correlation between LINE28DA and GROSS63DA is only $0.072 .^{18}$

Table 7 presents the full sample results from estimating equation (8), the effect of book discretionary accruals on tax discretionary accruals. Because firms potentially face immediate costs in recognizing income increasing accruals for tax and immediate benefits in recognizing income decreasing accruals, the specification of equation (8) allows for the explicit testing of this asymmetry. While $\alpha_{0}$ provides the intercept for the entire sample, $\alpha_{1}$ is the coefficient on a separate binary variable equal to one if the observation has negative taxable income, and controls for any difference in mean discretionary accruals of negative taxable income firms. To allow for differences in the pattern of income increasing and income decreasing accruals the discretionary accruals variable, BOОK28DA is split into two based on sign, BOОK28DA $>0$ and BOОK28DA $<0$, and potential differences in their effects can be tested by comparing the coefficients on each variable, $\beta_{1}$ and $\beta_{2}$. Since the tax costs of a taxable income increasing accrual are smaller for firms with negative tax net income an additional variable is included that interacts the discretionary accrual variables (BOOK28DA $>0$ and BOOK28DA $<0$ ) with a binary variable equal to one if the firm has negative tax net income. The coefficients on these variables, $\gamma_{1}$ and $\gamma_{2}$, are estimates of the additional effect tax status has on the reflection of book discretionary accruals in tax discretionary accruals. The combined effects of $\beta_{1}+\gamma_{1}$ and $\beta_{2}+\gamma_{2}$ can be compared to test if tax status has a statistically different effect on accruals behavior.

Given the systematic differences in the data taken from tax returns and that from

\footnotetext{
${ }^{18}$ Given the difference in total accruals is derived from the amount of the book-tax income difference it is possible that the difference in discretionary accruals is also determined by the magnitude of reported income difference. For System 1, the correlation of the difference in discretionary accruals between book and tax to the aggregate book-tax income difference is only 0.140, and 0.090 for System 2.
} 
financial statements, Equation (8) is estimated for two sets of data: in Column (1) the estimation uses matched tax and financial statement data while in Column (2) the estimation is performed using publicly-available data only. This side-by-side comparison provides an easy was to assess the effects of the differences in data on the outcome of the estimation. ${ }^{19}$ In both equations $\alpha_{0}$ is positive and significant, and $\alpha_{1}$ is negative and significant, implying that firms that are not taxable have, on average, lower (and negative) discretionary tax accruals.

The test of a central question of this paper, whether income increasing and decreasing discretionary book accruals are reflected to the same extent in taxable income, is found in the coefficient estimates for $\beta_{1}$ and $\beta_{2}$. Both sets of data yield the same result: discretionary accruals that increase book income are reflected to a lesser extent in taxable income than discretionary accruals that reduce book income $\left(\beta_{1}<\beta_{2}\right)$. For the tax return sample in Column (1), the estimated coefficient for book-increasing discretionary accruals implies that for each dollar of income increasing discretionary accrual recognized for financial reporting purposes, taxable income is increased by 0.341 dollars. By contrast, firms with income decreasing accruals are estimated to reduce taxable income by 0.761 of the amount. The relative magnitude of these coefficients is consistent with firms either taking advantage of opportunities to recognize greater financial reporting income when the tax reporting effects are small, or firms minimizing the tax effects of increased financial reporting income through other mechanisms. ${ }^{20}$

\footnotetext{
${ }^{19}$ While the data used in Column (2) are collected from public sources, inclusion in the sample is based on proprietary knowledge of the firm's tax consolidation. The similarity in consolidation should bias any empirical results to be more similar than would be expected without the constraint, and as such provides an upper bound on the similarity in results that a researcher would obtain if restricted to using publicly available data.

${ }^{20}$ The implied amount of additional tax paid, calculated as the estimated coefficient for taxable firms $(0.341)$ multiplied by the statutory tax rate (0.35), is 0.119 , similar to the value found by Erickson et al. (2002). This calculation is also an aggregate estimate of Shackelford et al. (2007) parameter of interest, $\left(\mathrm{M}_{2}-\delta \mathrm{M}_{3}\right) / \mathrm{M}_{1}$, representing the cash flow effects owing to taxation of reporting additional book income. The results here, and in
} 
Similarly, to the extent that firms recognize income decreasing accruals, they appear to be able to take advantage of the tax system to concurrently reduce taxable income. For the financial statement-only data, reported in Column (2) the results are statistically identical.

The next two coefficients, $\gamma_{1}$ and $\gamma_{2}$, capture the incremental effects of a firm having negative taxable income on the magnitude of discretionary accruals. For the tax return sample, the coefficient on book income increasing accruals $\left(\gamma_{1}\right)$ is 0.552 , implying that a much greater share of each dollar of additional book income, a total of $0.893(0.341+0.552)$, is reflected in taxable income when a firm is able to recognize the additional taxable income with little or no change in their tax liability. In the case of income decreasing accruals the estimate of $\gamma_{2}$ is -0.519 , implying that a smaller portion of the decrease in book income is reflected on a firm's tax return when they are unable to benefit from a concurrent reduction in taxable income. The Ftests of the equality of coefficients are provided at the bottom of the table, and show the differences between the coefficients on the accruals variables, $\beta_{1}$ and $\beta_{2}$, and the accruals variables interacted with tax status, $\beta_{1}+\gamma_{1}$ and $\beta_{2}+\gamma_{2}$, are statistically significant.

Reflecting the difficulties in identifying non-taxable firms documented in Tables 1 through 3 , the inferences from $\gamma_{1}$ and $\gamma_{2}$ differ across the two samples. In particular, $\gamma_{2}$, which captures the effect of an income decreasing book accrual on taxable income for a loss firm is 2.5 times the magnitude reported in Column (1) (-1.316 v -0.519), and the sum of $\beta_{2}$ and $\gamma_{2}$ is -0.555 , implying that book decreasing discretionary accruals are associated with increases in taxable income in the same period. Further, the adjusted $\mathrm{R}^{2}$ in the public data sample is substantially lower than in the tax return matched sample, 0.04 versus 0.28 .

the next section, show that this trade-off varies by both tax status and industry. 
In summary, the aggregate results provide evidence that income-decreasing accruals are reflected to a greater degree on the tax return than income increasing accruals when the tax savings from such decreases are the greatest $\left(\beta_{2}>\beta_{1}\right)$. However, when tax costs are reduced owing to a current period loss, income-increasing accruals are contemporaneously reflected to a greater degree in current taxable income $\left(\beta_{1}+\gamma_{1}>\beta_{2}+\gamma_{2}\right) .^{21}$

\section{B. Industry effects}

Heterogeneity in accounting rules and/or practices suggests that the aggregate results described above may not be representative of every industry. To explore possible differences across industries Table 8 provides separate results for the non-manufacturing and manufacturing sectors along with a number of subindustries (nine subindustries for nonmanufacturing and nineteen for manufacturing).

The first column of Table 8, Panel A, provides aggregate results for non-manufacturing firms, and are similar to the results for the entire sample. The estimated coefficient for book income increasing discretionary accruals (BOOK28DA>0) implies that for each dollar of income increasing discretionary accrual recognized for financial reporting purposes, taxable income is increased by only 0.348 dollars. By contrast, firms with income decreasing accruals are estimated to reduce taxable income by 1.042 of the amount. Similar to the results reported in Table 7, the coefficient estimates are consistent with income increasing and decreasing discretionary accruals being reflected differently in taxable income, and that firms recognize

\footnotetext{
${ }^{21}$ This result is consistent with, but more general, than Calegari (2000), who found that firms use accruals with low book-tax conformity to manage book earnings and high conformity to manage tax. The results here show the degree of conformity between book and tax accruals depends on the tax status of the firm.
} 
greater financial reporting income when the tax reporting effects are small. Similarly, when firms recognize income decreasing accruals, they appear to be able to take advantage of the tax system to concurrently reduce taxable income. The effects of tax status $\left(\gamma_{1}\right.$ and $\left.\gamma_{2}\right)$ are also similar to those reported for the entire sample, with income increasing accruals being reflected to a much greater extent on the tax return when the tax costs are low (0.926 versus 0.337 ).

Columns 2 through 10 of Panel A provide the results for each two-digit SIC nonmanufacturing industry group. In all cases, $\beta_{1}$, the coefficient on BOOK28DA $>0$ is positive and statistically significant, and ranges from 0.230 (services) to 1.034 (wholesale trade). Consistent with expectations, regulated industries has a coefficient statistically indistinguishable from one (0.985), consistent with a close regulatory ties between financial and tax reporting of positive accruals. For $\beta_{2}$, the coefficient on income decreasing accruals, all of the coefficients are positive and all but two (for Mineral Industries and Public Administration) are significant. In four of the nine industries the hypothesis that $\beta_{1}=\beta_{2}$ cannot be accepted, and in three of those four industries (Agriculture, Minerals, Regulated Industries) $\beta_{1}>\beta_{2}$. Only in Services is $\beta_{2}$ estimated to be significantly greater than $\beta_{1}$.

The effects of negative taxable income also differ across the industries. For income increasing accrual firms $\gamma_{1}$ is significant in five of the nine industries, but positive in only one, Services, suggesting that the aggregate result may be strongly influenced by this industry (Services comprise 30 percent of the sample). The coefficient on the interaction of negative taxable income with income decreasing accruals is negative and significant in two of the industries (Construction and Services) and positive and significant in Regulated Industries. With respect to the combined coefficients, $\beta_{1}+\gamma_{1}$ and $\beta_{2}+\gamma_{2}$, only two of the industries' 
combined coefficients are estimated to be statistically different, Regulated Industries and Services. For Regulated Industries, income increasing accruals of firms with positive taxable income ( $\left.\beta_{1}=0.985\right)$, and income decreasing accruals of firms with negative taxable income ( $\beta_{2}$ $\left.+\gamma_{2}=1.025\right)$ are statistically indistinguishable.

Panels B and C of Table 5 provide estimates for the manufacturing sector in total, and separately for each of the 19 sub-industries. While both $\beta_{1}$ and $\beta_{2}$ for the manufacturing sample (Column (1)) are positive, as in prior tables, they are not statistically distinguishable from each other. However, the sum of the coefficients of $\beta_{1}+\gamma_{1}$ and $\beta_{2}+\gamma_{2}$ are significantly different, and are consistent with both the aggregate results and those reported for non-manufacturing firms. In sum, for the manufacturing sector as a whole, as for the aggregate non-manufacturing sector, income decreasing accruals are reflected differently on the tax return than income increasing accruals, with income increasing accruals reflected on the tax return to a greater extent when the tax cost of doing so is small. As in the non-manufacturing industries, income decreasing accruals are reflected less on the tax return when the firm has a tax loss than when it is currently taxable.

Examining the individual industries, all but one of the estimates of $\beta_{1}$ are positive and significant, with the exception of Leather which is not significant, and has only 13 observations. All but three of the estimates of $\beta_{2}$ (Leather, Instruments, and Paper) are significant, and all are positive. Comparing $\beta_{1}$ to $\beta_{2}$, in eleven of the nineteen industries the coefficients are not statistically different from each other. In the remaining eight, in all but one industry (Electrical Equipment) $\beta_{1}$ is larger than $\beta_{2}$, opposite the result found in the aggregate, and implying that for these industries increases in book income are reflected to a greater degree in taxable income than 
decreases.

Examining the effects of the interaction with tax status, $\beta_{1}+\gamma_{1}$ and $\beta_{2}+\gamma_{2}$, the sums of the coefficients are estimated to be statistically different in 5 of the 19 industries, and in all but one of the five the results are consistent with the aggregate results for manufacturing: book income increasing accruals are reflected in taxable income to a greater extent when the tax cost is small. The exception, Transportation Equipment, yields a large negative coefficient on $\gamma_{1}$, implying that increases in book accruals are associated with contemporaneous decreases in taxable income of firms that already have negative taxable income.

Taken together, the results of Table 8 provide evidence that financial reporting discretionary accruals and tax discretionary accruals are related, that the relation varies significantly by industry, and that income increasing book accruals are reflected less in taxable income than income decreasing accruals unless the tax costs are small. The extent of the interindustry differences can be significant, and suggest that empirical analyses should allow for differences in the conformity of book and tax reporting beyond the common practice of omitting regulated industries (because they are asserted as being highly conforming) and financial institutions (because of their general accounting differences). Similar to controlling for country differences in book-tax conformity in the international literature (e.g., Hung, 2000), the coefficient estimates in Table 8 provide a set of variables that can be used to control for crosssectional differences in conformity in empirical accounting research using Compustat or other U.S. data.

Eliminating the use of proprietary data, Table 9 presents the estimated relation between book and tax accruals when a financial statement-based measure of taxable income is used in 
place of the tax return data. For this table, the same methodology used in Table 8 was repeated with GROSs63 substituted for the tax return measure of tax net income, beginning with the joint estimation of equations (6) and (7). From the estimation of the system of equations, the correlation matrix of the residuals are reported in the last column of Table 6, along with their significance. Similar to System 1, the statistical significance of the correlation of the residuals supports the conclusion that FGLS is a more appropriate method to estimate the total accruals model than single equation OLS.

The contrast to the results presented in Table 8 can be seen by comparing the aggregate results for non-manufacturing and manufacturing from Panels A and B of each table. Qualitatively, and quantitatively, the results for non-manufacturing industries are quite similar, with $\beta_{1}<\beta_{2}$ and $\left(\beta_{1}+\gamma_{1}\right)>\left(\beta_{2}+\gamma_{2}\right)$. For manufacturing, the aggregate results are more difficult to compare, with significant differences in both the magnitude of the coefficients (especially those on the terms interacted with negative taxable income) and the F-tests of the differences in coefficients. It is also worth noting that the adjusted $\mathrm{R}^{2}$ of the non-manufacturing and manufacturing totals are substantially lower in Table 9 than in Table 8.

The most important conclusion from examining Table 9 is not related to the significance of individual coefficient estimates in each industry, but the general result that financial statement-based measures of tax discretionary accruals do not provide the same inferences about firm behavior as suggested by the underlying tax return data. While the joint estimation of a financial statement -based tax accruals model with a financial statement measure of book accruals yields more efficient estimates of the parameters of an accruals model, a result that has methodological implications for estimating accruals models generally, the residuals from the tax 
equation will not yield comparable results to those that would be obtained from the use of tax return data. This lack of similarity is particularly noteworthy given that the consolidation rules imposed on the sample made the two samples more, rather than less, homogeneous.

C. The financial reporting costs of tax minimizing behavior

Up to this point, I have focused on the relation of financial reporting to tax reporting. However, from a tax policy perspective, numerous factors (such as greater disparities in booktax differences over time, suggestions of increased tax sheltering activities, and most recently the reports on Enron's tax practices by the Joint Committee on Taxation (2003) and the Senate's Permanent Subcommittee on Investigations (2003)) have highlighted the abilities of firms to aggressively manage their tax reporting income using transactions that affect only taxable income, with no (or very little ) consequence for the amount of pretax income reported to shareholders. Bankman (1999) provides anecdotal evidence on a variety of tax shelter schemes that do not reduce book income. Weisbach (2001), in commenting on the proliferation of tax reduction activities of concern to the U.S. Treasury argues that "[v]irtually no shelters in the current market reduce book income." According to the JCT (2003) report, twelve Enron transactions between 1995 and 2001 yielded more than \$2 billion in additional financial accounting income through reductions in the tax expense.

While Enron's ability to separately manipulate its book and taxable income is striking, it might be considered an outlier given the spectacular collapse of the company. However, from both a financial and tax reporting perspective, the mechanisms used by Enron are not particularly exotic, and many are widely marketed "retail" schemes. Bankman (2003) reports that the ability 
to engage in aggressive tax shelters has not only become more available generally, but that such tax sheltering activities, even those with a very high chance of detection, remain profitable even if detected and resolved through a settlement agreement with the IRS. This anecdotal evidence on firm behavior suggests the statistical relations documented above for the contemporaneous behavior of the tax return to financial statements may not be symmetric in reverse. While the incentive to report less income to tax authorities leads to the prediction that income increasing book accruals will have smaller coefficients than income decreasing book accruals, the opposite will be true of tax motivated transactions. If the tax return is the starting point, then recent experience with tax shelters implies that tax income increasing discretionary accruals will be reflected in financial statements, while discretionary accruals that decease taxable income will not.

To test this, equation (8) is estimated with BOOKDA as the dependent variable and the change in discretionary tax accruals (LINE28DA or GROSS63DA) as the explanatory variable with the results for the pooled data presented in Table 10. In contrast to Table 7, where the coefficient on income increasing book accruals was found to have a smaller effect on taxable income than income decreasing accruals, the magnitude of the estimates of $\beta_{1}$ and $\beta_{2}$ are reversed, and statistically different, with $\beta_{1}>\beta_{2}(1.247>0.571)$. These coefficients imply that income tax increasing accruals are reflected to a higher degree in book income than accruals that decrease taxable income. This relation is consistent with the firms being willing to pay higher taxes if they are concurrently reporting higher income to their shareholders, or, alternatively, that firms that increase their taxable income do so in a manner than conforms with financial reporting. 
Firms with negative taxable income can increase their current year taxable income without generating additional tax liability, and decreases to their income will not provide immediate additional tax savings. However, for negative taxable income firms, taxable income increasing accruals are reflected less in current book income than taxable income decreasing accruals (0.350 versus 0.637$)$. This implies that the nature of income decreasing accruals taken by firms with negative taxable income are generally more conforming with financial accounting rules than other accruals. However, as will be shown in the disaggregated industry results to follow, this counterintuitive result is driven by the Services industry, which comprises 17 percent of the sample. Excluding Services, the point estimate for with $\beta_{1}$ still exceeds $\beta_{2}(0.908$ versus $0.760)$ and $\beta_{1}+\gamma_{1}$ is also greater than $\beta_{2}+\gamma_{2}$ (0.451 versus 0.444$)$, but the differences are not statistically significant.

The results from the use of publicly available data, presented in Column (2), present a starkly different picture than those using tax return information. Neither of the discretionary accruals variables $\left(\beta_{1}\right.$ and $\left.\beta_{2}\right)$ are statistically significant and the interaction of income increasing accruals and NEGTI $\left(\gamma_{1}\right)$ is estimated to have a value of 0.994 , implying that the incremental effect for a firm currently experiencing a tax loss is to reflect all of the increase in taxable income in current period financial reporting income. While this result, as well as the results of the combined coefficients $\left(\beta_{1}+\gamma_{1}\right.$ and $\left.\beta_{2}+\gamma_{2}\right)$ are consistent with expectations, they are not consistent with the tax return results. As is Table 7, the $\mathrm{R}^{2}$ in reported in Column (2) is much smaller than reported in Column (1) for the matched tax return sample.

Table 11 provides industry-level results for the financial reporting effects of tax discretionary accruals, paralleling those presented in Table 8 for non-manufacturing and 
manufacturing industries. The aggregate results for non-manufacturing industries are presented in Panel (A), Column (1), and are similar to the aggregate results reported in Table 10, with $\beta_{1}$ > $\beta_{2}(1.445>0.466)$ and a large, negative, estimate for $\gamma_{1}$, consistent with taxable income increasing accruals being reflected to a larger extent in financial reporting income, but that negative current period taxable income significantly reduces the effect $\left(\gamma_{1}=-1.117\right)$, and increases the amount of taxable income decreasing accruals reflected in financial reporting income $\left(\gamma_{2}=0.533\right)$. Service industry firms comprise 30 percent of the non-manufacturing sample total, and as in the aggregate results presented in Table 10, have a significant effect on the industry results. Excluding the service industry (not reported in the table), the point estimate for $\beta_{1}$ still exceeds $\beta_{2}$ (0.923 versus 0.707 ), a difference that is significantly significant, but the point estimates for $\beta_{1}+\gamma_{1}$ and $\beta_{2}+\gamma_{2}$ are statistically indistinguishable (0.766 versus 0.840 ).

While the aggregate results for non-manufacturing firms are consistent with the hypothesis that taxable income increasing accruals are reflected to a greater degree in book income than income decreasing accruals, the effects clearly vary by industry, as shown in Columns (2) through (10). In eight of the nine non-manufacturing industries, the point estimate for $\beta_{1}$ exceeds $\beta_{2}$ (Agriculture is the exception), but the difference is statistically significant in only three industries (Agriculture, FIRE, and Services). Similarly, the point estimates for $\beta_{1}+\gamma_{1}$ and $\beta_{2}+\gamma_{2}$ are statistically distinguishable in only three industries (Agriculture, Construction, and FIRE).

Panels (B) and ( C) provide the disaggregated results for manufacturing firms. In contrast to the results for the non-manufacturing sector, the point estimates for the manufacturing sector as a whole are consistent with the hypothesis that taxable income increasing accruals are 
reflected to a greater degree in book income regardless of their current tax status, but the coefficients between the groups are not statistically distinguishable. Similar to Table 8, eight of the 19 manufacturing industries have statistically different coefficients for $\beta_{1}$ and $\beta_{2}$ and five industries for $\left(\beta_{1}+\gamma_{1}\right)$ versus $\left(\beta_{2}+\gamma_{2}\right)$. Point estimates for twelve of the nineteen industries are consistent with there being greater conformity for taxable income increasing accruals when firms have negative taxable income (and therefore face lower costs to increase taxable income), including the five industry groups contributing 68 percent of the observations (Chemicals, Electrical Equipment, Instruments, Industrial Machinery, and Food)

The general conclusions to be drawn from Table 11 are that accruals that increase taxable income, and for which there is an additional tax cost, tend to be more conforming, with an increase in book income of 0.887 of the amount for manufacturing firms, and 1.445 for nonmanufacturing firms. With respect to decreases in income, manufacturing firms appear to be more conforming than non-manufacturing (0.827 versus 0.466$)$. While there are significant exceptions within the manufacturing sector, the effect of tax status on the conformity of accruals appears to be more pronounced in non-manufacturing industries than in manufacturing.

\section{Conclusions}

The extent of the trade-off between financial and tax reporting is an important issue in understanding firms’ behavior, and in the current policy debate over the adequacy of firms’ disclosures of tax related information. Using a matched sample of financial statements with tax returns I estimate the extent to which discretionary financial reporting accruals are correlated with discretionary tax accruals. The methodology takes advantage of the contemporaneous 
nature of financial and tax reporting to mitigate the econometric problems identified in earlier earnings management studies. There are two broad conclusions from this work.

First, with respect to recent policy discussions regarding the need for greater disclosure of tax return information, the results show that financial statement disclosures under FAS 109 do not convey sufficient information to adequately estimate key aspects of a firm’s tax attributes, such as the current year tax liability. While the disclosure of some information from the tax return might address this issue, changes to the financial accounting disclosures under FAS109 may be equally effective.

Second, I find the degree to which tax reporting is affected by discretionary financial reporting varies significantly by industry, profitability, and by the sign of discretionary accruals. These results show that managers are able to undertake substantial book income increasing activities without being subject to immediate tax reporting costs, consistent with recent evidence on the differential growth of book and tax income and with tax sheltering activities. Further, the extent to which tax discretionary accruals are affected by book discretionary accruals varies by both the sign of the accrual and the firm's tax status, consistent with the nature of discretionary accruals being such that managers can opportunistically mitigate the tax consequences of such activities, such as by recognizing more earnings when the tax costs are low.

There are a number of extensions to these results for future research to address. First, industry-based studies are commonplace, and while the results show aggregate differences by industry, the specific characteristics of individual firms are likely to be important in determining the reporting tradeoffs of firms. As a result, future research on the components of book tax differences can provide additional information on specific reporting choices, and whether their 
reporting tradeoffs are likely to be high or low.

Second, evidence of earnings management has been derived from the distribution of earnings (Burgstahler and Dichev, 1997), and Phillips et al. (2003) have shown the deferred tax expense is incrementally useful in detecting earnings management. The results of this paper, while addressing the link between income reported under each system, does not address how such differences affect the reporting of current and deferred tax expenses. The results do support the importance of additional research on the components of deferred taxes by documenting the lack of similarity in results when aggregate financial reporting data is used in place of tax return information.

Separately, the paper provides a new methodological approach to address concerns with discretionary accruals-based earnings management. Easier to implement than the instrumental variables approach suggested by Kang and Sivaramakrishnan (1995), it takes advantage of the contemporaneous determination of financial and tax income to control for omitted variables. 


\section{References}

Bankman, J. 1999 "The new market in corporate tax shelters" Tax Notes 83:12 (June 21) pp.1775-1795

Bankman, J., 2003, “An Academic’s View of the Tax Shelter Battle,” working paper, Stanford Law School.

Boynton, C.E., DeFilippes, P., Lisowsky, P., Mills, L. 2004, “Consolidation Anomalies Suggest Cautious Interpretation of Schedule M-1 Book-Tax Differences and Schedule L Balance Sheets,” Tax Notes (July 26).

Boynton, C.E, Dobbins, P., Plesko, G.A.1992. "Earnings management and the corporate Alternative Minimum Tax. Journal of Accounting Research, 30 (Supplement): 131 - 153

Burgstahler, D., Dichev, I., 1997. “Earnings management to avoid earnings decreases and losses,”.Journal of Accounting and Economics 24, 99-126.

Calegari, M. J., 2000. "The effect of tax accounting rules on capital structure and discretionary accruals." Journal of Accounting and Economics 30: 1-31.

Dechow, P., Sloan, R., Sweeney, A.. 1995. “Detecting earnings management” The Accounting Review 70: 193-225.

Desai, M. A. 2003. "The divergence between book and tax income." Tax Policy and the Economy 17: 169-206 (Cambridge: NBER).

Dworin, L., 1985, "On estimating corporate tax liabilities from financial statements." Tax Notes, (December 2): 965-971

Engel, E., Erickson, M., Maydew, E.J.1999, “Debt-equity hybrid securities,” Journal of Accounting Research, 37: 1-26.

Erickson, M., Hanlon, M., and Maydew, E.J. 2004, "How Much Will Firms Pay for Earnings That Do Not Exist? Evidence of Taxes Paid on Allegedly Fraudulent Earnings. The Accounting Review, 79: 2, p p. 387 - 408.

Fields, T.D., Lys, T.Z., Vincent, L. 2001, “Empirical research on accounting choice, Journal of Accounting and Economics v 34 Nos. 1-3, pp. 255-307.

Gramlich, J., 1991. The effect of the alternative minimum tax book income adjustment on accrual decisions. Journal of the American Taxation Association 13 (1), 36-56. 
Grassley, C., 2006,“Opening Statement: ‘A Tune-up on Corporate Tax Issues: What’s Going on Under the Hood?’” U.S. Senate Committee on Finance, (June 13).

Greene, W.H., 1997, Econometric Analysis, $3^{\text {rd }}$ edition (Prentice-Hall, Englewood Cliffs).

Hanlon, M. 2003. "What Can We Infer About A Firm's Taxable Income From Its Financial Statements?", National Tax Journal 56:4 (December), 831-864.

Hanlon, M., Shevlin, T., 2002, “Accounting for tax benefits of employee stock options and implications for research,” Accounting Horizons 16, 1 - 16.

Hung, M. 2000. "Accounting standards and value relevance of financial statements: An international analysis." Journal of Accounting and Economics 30(3): 401-420.

Hunt, A.,Moyer S.E., Shevlin, T. 1996, "Managing interacting accounting measures to meet multiple objectives: A study of LIFO firms," Journal of Accounting and Economics v 21 No. 3, pp. 339-374.

Joint Committee on Taxation, 2003, "Report of Investigation Of Enron Corporation And Related Entities Regarding Federal Tax And Compensation Issues, And Policy Recommendations" (JCS-3-03).

Jones, J., 1991, "The effects of foreign trade regulation on accounting choices," Journal of Accounting Research, v. 29: 193 - 228.

Kang, S.-H., Sivaramakrishnan, K. 1995. "Issues in testing earnings management and an instrumental variable approach,” Journal of Accounting Research 33, 353-367.

Kleinbard, E.D., 2006, Testimony before the Committee on Finance, United States Senate, “A Tune-up on Corporate Tax Issues: What’s Going on Under the Hood?’ (June 13).

Kothari, S.P., 2001, “Capital markets research in accounting,” Journal of Accounting and Economics 31 Nos. 1-3, pp. 105 - 231.

Manzon, G., 1992. Earnings management of firms subject to the alternative minimum tax. Journal of the American Taxation Association 14 (2), 88-111.

Manzon, G.B., and Plesko, G. A. 2002, "The relation between financial and tax reporting measures of income," Tax Law Review 55, 175 - 214.

Manzon, G.B., and Plesko, G. A, 2007, "Strategic Disclosure for Political Gain: the Case of the Corporate Alternative Minimum Tax.” working paper. 
Matsunaga, S., Shevlin, T., Shores, D. 1992, "Disqualifying dispositions of incentive stock options: Tax benefits versus financial reporting costs,” Journal of Accounting Research, Vol. 30, pp. 37-68.

Maydew, E.L., 2001, “Empirical tax research in accounting: A discussion,” Journal of Accounting and Economics v 34 Nos. 1-3, pp. 389 - 403.

McGill, G., and Outslay, E. 2004. "Lost in Translation: Detecting Tax Shelter Activity in Financial Statements," National Tax Journal 57 (September), pp. 739-756.

McNichols, M., 2000, "Research design issues in earnings management studies", Journal of Accounting and Public Policy, Vol. 19, Issues 4-5, pp. 313-345.

McNichols, M., Wilson, G.P. 1988, “evidence of earnings management from the provision for bad debts,” Journal of Accounting Research, 26 (Supplement): 1 - 31.

Mills, L.F., 1998, “Book-tax differences and Internal Revenue Service Adjustments,” Journal of Accounting Research, 36: 343 - 356.

Mills, L. F., Newberry, K., Trautman, W. 2002, "Trends in Book-tax income and Balance Sheet Differences," Tax Notes August 19, 2002, 1109-1124.

Mills, L.F., Newberry, K., Novack, G.F. 2003, How well do Compustat NOL Data Identify Firms with U.S. Tax Return Loss Carryovers? forthcoming, Journal of the American Taxation Association.

Mills, L.F., Plesko, G. A, 2003, "Bridging the reporting gap: a proposal for more informative reconciling of book and tax income”, National Tax Journal 56:4 (December), 865 - 893.

Permanent Subcommittee on Investigations, 2003, "Report On Fishtail, Bacchus, Sundance, and Slapshot: Four Enron Transactions Funded and Facilitated By U.S. Financial Institutions," U.S. Senate, Committee on Governmental Affairs, (January 2).

Phillips, J.,. Pincus, M., Rego, S. 2003. Earnings management: new evidence based on deferred tax. "Earnings management: new evidence based on deferred tax expense." The Accounting Review 78 (2003): 491-521.

Plesko, G.A., 2000a, “Book-tax differences and the measurement of corporate income,” in Proceedings of the Ninety-Second Annual Conference, (Washington D.C.: National Tax Association - Tax Institute of America), 171-176.

Plesko, G.A., 2000b, "Evidence and theory on corporate tax shelters," in Proceedings of the Ninety-Second Annual Conference, (Washington D.C.: National Tax Association - Tax Institute of America), 367-371. 
Plesko, G.A., 2002, "Reconciling corporation book and taxable net income, tax years 1996 1998,” (Spring) SOI Bulletin (U.S. Government Printing Office), 111 - 132.

Plesko, G.A., 2003, “An evaluation of alternative measures of corporate tax rates,” Journal of Accounting and Economics 35:2 (April 2003) pp. 201 - 226.

Plesko, G.A., 2004, “Corporate Tax Avoidance and the Properties of Corporate Earnings”, National Tax Journal 57:3 (September), pp. 729 -737.

Plesko, G.A., and Shumofsky, N. 2004, "Reconciling Corporations' Book and Taxable Income, 1995 - 2001," SOI Bulletin, Winter 2004-2005 (Washington D.C.: US Government Printing Office) pp 103-108..

Schler, M.L., 2002, "Ten more truths about tax shelters: The problem, possible solutions, and a reply to Professor Weisbach," Tax Law Review 55, 325 - 395.

Scholes, M., Wilson, G.P., Wolfson, M. 1992. “Firms' responses to anticipated reductions in tax rates: the Tax Reform Act of 1986" Journal of Accounting Research 30 (Suppl.), 161-191.

Scholes, M.S., Wolfson, M.A., Erickson, M., Maydew, E.L., Shevlin, T. 2002, Taxes and Business Strategy: A Planning Approach 2ed, (Prentice-Hall, Englewood Cliffs).

Shackelford, D.A., T. Shevlin, 2001, "Empirical tax research in accounting," Journal of Accounting and Economics v 34 Nos. 1-3, pp. 321-387.

Shackelford, D.A., Slemrod, J., Sallee, J. 2007, “A Unifying Model of How Taxes Affect the Real and Accounting Decisions of Corporations,” working paper.

Smith, D.T., Butters, J.K. 1949, Taxable and Business Income (NBER, New York).

Sullivan, M. 1999, "Shelter fallout? Corporate taxes down, profits up" Tax Notes 84:5 (Aug 2) pp.653-657

Talisman, J., 2000, “Penalty and Interest Provisions, Corporate Tax Shelters” U.S. Department of the Treasury Testimony before the Senate Committee on Finance (March 8)

Thomas, J., Zhang, X. 2000, "Identifying unexpected accruals: A comparison of current approaches", Journal of Accounting and Public Policy, Vol. 19, Issues 4-5, pp. 347-376.

U.S. Department of the Treasury, 1999, The Problem of corporate tax shelters: Discussion, analysis and legislative proposals, Washington, D.C.: U.S. Government Printing Office.

U.S. Internal Revenue Service, 2004, Statistics of Income - 2001: Corporation Income Tax 
Returns, (Publication 16) (Washington D.C.: US GPO).

Weisbach, D.A., 2002, "Ten truths about tax shelters," Tax Law Review 55, 215 - 253.

Yin, G.K., 2001, "Business Purpose, Economic Substance, and Corporate Tax Shelters: Getting Serious About Corporate Tax Shelters: Taking a Lesson from History." Southern Methodist University Law Review 54:1 (Winter 2001): pp. 209 - 238. 
Table 1

Comparison of Financial Statement and Tax Return Data

\begin{tabular}{|c|c|c|c|c|c|c|}
\hline & (A) & (B) & (c) & (D) & (E) & $(\mathrm{F})$ \\
\hline & \multicolumn{2}{|c|}{$\mathrm{N}=37,853$} & \multicolumn{2}{|c|}{$\mathrm{N}=17,617$} & \multicolumn{2}{|c|}{$\mathrm{N}=6,062$} \\
\hline & $\begin{array}{c}\text { Mean } \\
\text { (Standard Deviation) }\end{array}$ & $\mathrm{t}$ & $\begin{array}{c}\text { Mean } \\
\text { (Standard } \\
\text { Deviation) }\end{array}$ & $\mathrm{t}$ & $\begin{array}{c}\text { Mean } \\
\text { (Standard } \\
\text { Deviation) }\end{array}$ & $\mathrm{t}$ \\
\hline Book Total Assets (data 6) & $\begin{array}{c}1,348.06 \\
(10,255.12)\end{array}$ & \multirow[b]{2}{*}{$-9.67^{* * *}$} & \multirow{2}{*}{$\begin{array}{c}916.96 \\
(13,581.7)\end{array}$} & & \multirow{2}{*}{$\begin{array}{c}612.27 \\
(3,125.30)\end{array}$} & \\
\hline Tax Total Assets & $\begin{array}{c}1,552.34 \\
(11,682.14)\end{array}$ & & & & & \\
\hline Book Total Revenues (data12) & $\begin{array}{c}1,045.59 \\
(4,831.29)\end{array}$ & \multirow{2}{*}{$14.00^{* * *}$} & $\begin{array}{c}454.94 \\
(2,051.66)\end{array}$ & \multirow{2}{*}{0.81} & $\begin{array}{c}489.30 \\
(1,798.83)\end{array}$ & \multirow{2}{*}{0.38} \\
\hline Tax Gross Receipts & $\begin{array}{c}904.68 \\
(4,082.94)\end{array}$ & & $\begin{array}{c}439.43 \\
(3,143.94)\end{array}$ & & $\begin{array}{c}487.24 \\
(1,763.03)\end{array}$ & \\
\hline $\begin{array}{l}\text { Pre-Tax Book Income } \\
\text { (data 170) }\end{array}$ & $\begin{array}{c}64.41 \\
(600.23)\end{array}$ & \multirow{2}{*}{0.71} & $\begin{array}{c}22.92 \\
(275.84)\end{array}$ & \multirow{2}{*}{$3.47^{* * *}$} & $\begin{array}{c}23.81 \\
(244.66)\end{array}$ & \multirow{2}{*}{$1.87^{*}$} \\
\hline $\begin{array}{l}\text { Pre-Tax Book Income } \\
\text { (Schedule M-1) }\end{array}$ & $\begin{array}{c}62.78 \\
(636.05)\end{array}$ & & $\begin{array}{l}20.44 \\
(245.31)\end{array}$ & & $\begin{array}{c}22.08 \\
(225.13)\end{array}$ & \\
\hline $\begin{array}{l}\text { Estimated Taxable Income } \\
\text { (GRoss63 = data63/rate }+\Delta \text { data52) }\end{array}$ & $\begin{array}{c}52.10 \\
(288.81)\end{array}$ & & $\begin{array}{c}24.40 \\
(168.14)\end{array}$ & & $\begin{array}{c}23.59 \\
(108.30)\end{array}$ & \\
\hline $\begin{array}{l}\text { Tax Net Income } \\
\text { (LiNE28) }\end{array}$ & $\begin{array}{c}50.25 \\
(404.24)\end{array}$ & 1.45 & $\begin{array}{c}14.88 \\
(183.80)\end{array}$ & $13.83^{* * *}$ & $\begin{array}{c}15.74 \\
(165.56)\end{array}$ & $9.84^{* * * *}$ \\
\hline Income Subject to Tax & $\begin{array}{c}50.51 \\
(362.53)\end{array}$ & 1.25 & $\begin{array}{c}19.91 \\
(154.53)\end{array}$ & $6.63^{* * *}$ & $\begin{array}{c}20.04 \\
(125.84)\end{array}$ & $6.00^{* * * *}$ \\
\hline $\begin{array}{l}\text { Current Tax Expense } \\
\text { (data 63) }\end{array}$ & $\begin{array}{c}18.23 \\
(101.08)\end{array}$ & & $\begin{array}{c}8.54^{\dagger} \\
(58.85)\end{array}$ & & $\begin{array}{c}8.26^{\dagger} \\
(37.91)\end{array}$ & \\
\hline Tax Before Credits & $\begin{array}{c}20.16 \\
(134.19)\end{array}$ & $-4.64^{* * *}$ & $\begin{array}{c}8.10 \\
(57.92)\end{array}$ & $2.71^{* * * *}$ & $\begin{array}{c}7.92 \\
(31.82)\end{array}$ & $1.65^{*}$ \\
\hline Tax After Credits & $\begin{array}{l}14.88 \\
(86.03)\end{array}$ & $33.59^{* * *}$ & $\begin{array}{c}7.54 \\
(53.74)\end{array}$ & $6.45^{* * *}$ & $\begin{array}{c}7.39 \\
(29.86)\end{array}$ & $4.25^{* * *}$ \\
\hline
\end{tabular}

This table presents the financial and tax reporting values, respectively, of data obtained from SEC 10-K filings and IRS Form 1120. Book Total Assets is taken from Compustat (data item 6); Tax Total Assets is taken from the IRS Form 1120, Schedule L. Book Total Revenues (Compustat data item 2) and Tax Gross Receipts (IRS Form 1120, page 1) are the amounts of receipts reported to shareholders and tax authorities, respectively. Pre-tax Book income for financial reporting purposes is measured as Compustat data item 170; the tax return value is taken from the IRS Form 1120, Schedule M-1. Estimated taxable income is based information available in Compustat and is defined as the Current Tax Expense (data item 63) grossed-up by the year's maximum corporate tax rate, adjusted for the change in Net Operating Loss (NOL, data item 52). Tax Net Income is derived from line 28 of the tax return, further reduced by the amount of special deductions. Income Subject to Tax, Tax Before, and Tax After, Credits are all taken from the tax return.

Column (A) presents the means and standard deviation of the book and tax variables from the unconstrained sample. Column (B) presents the results of t-tests where $\mathrm{H}_{0}$ tests that the book value - the tax value is equal to zero. Column ( $\mathrm{C}$ ) presents the means and standard deviations of a sample matched on firms' reported total assets only and Column (E) from the constrained sample used in the estimation of the accruals models. Columns (D) and (F) present the t-tests of the means of the constrained sample variables. Significance levels: $* * * 1$ percent, ${ }^{* * 5}$ percent, ${ }^{* 10}$ percent.

${ }^{\dagger}$ Owing to missing values for Compustat data item 63 the sample sizes for the current tax expense are reduced. 15,496 observations were used in Column (C) and 5,392in Column (E). 
Table 2

Sign Errors in Financial Statement-Based Measures of Taxable Income Cell Entries of Percent of total Sample Falling into Each Category

\begin{tabular}{|c|c|c|c|}
\hline & & \multicolumn{2}{|c|}{$\begin{array}{c}\text { Sign of } \\
\text { Estimated Taxable Income (GRoss63) }\end{array}$} \\
\hline & & $\leq 0$ & $>0$ \\
\hline \multirow{2}{*}{$\begin{array}{l}\text { Sign of } \\
\text { Tax Net Income (LINE 28) } \\
(\mathrm{N}=37,853)\end{array}$} & $\leq 0$ & 35.08 & 6.92 \\
\hline & $>0$ & 5.24 & 52.76 \\
\hline Misclassification & & \multicolumn{2}{|c|}{$12.16 \%$} \\
\hline \multirow{2}{*}{$\begin{array}{l}\text { Sign of } \\
\text { Tax Net Income (LINE 28) } \\
(\mathrm{N}=17,617)\end{array}$} & $\leq 0$ & 37.22 & 9.04 \\
\hline & $>0$ & 3.97 & 49.78 \\
\hline Misclassification & & \multicolumn{2}{|c|}{$13.01 \%$} \\
\hline \multirow{2}{*}{$\begin{array}{l}\text { Sign of } \\
\text { Tax Net Income (LINE 28) } \\
(\mathrm{N}=6,062)\end{array}$} & $\leq 0$ & 36.16 & 8.43 \\
\hline & $>0$ & 4.03 & 51.39 \\
\hline Misclassification & & \multicolumn{2}{|c|}{$12.46 \%$} \\
\hline
\end{tabular}


Table 3

Sign Errors in Financial Statement-Based Measures of Tax Liability Cell Entries of Percent of Total Sample Falling into Each Category

\begin{tabular}{|c|c|c|c|c|c|}
\hline & & \multicolumn{2}{|c|}{$\begin{array}{c}\text { Sign of } \\
\text { Tax Before Credits }\end{array}$} & \multicolumn{2}{|c|}{$\begin{array}{c}\text { Sign of } \\
\text { Tax After Credits }\end{array}$} \\
\hline & & $\leq 0$ & $>0$ & $\leq 0$ & $>0$ \\
\hline \multirow{2}{*}{$\begin{array}{l}\text { Sign of data63 } \\
\text { Current Income Taxes - } \\
\text { Federal } \\
(\mathrm{N}=37,853)\end{array}$} & $\leq 0$ & 38.51 & 1.81 & 35.91 & 4.40 \\
\hline & $>0$ & 12.71 & 46.97 & 6.55 & 53.14 \\
\hline Misclassification & & \multicolumn{2}{|c|}{14.52} & \multicolumn{2}{|c|}{10.95} \\
\hline \multirow{2}{*}{$\begin{array}{l}\text { Sign of data } 63 \\
\text { Current Income Taxes - } \\
\text { Federal } \\
(\mathrm{N}=17,617)\end{array}$} & $\leq 0$ & 40.46 & 0.73 & 38.22 & 2.97 \\
\hline & $>0$ & 16.04 & 42.77 & 8.72 & 50.09 \\
\hline Misclassification & & \multicolumn{2}{|c|}{16.77} & \multicolumn{2}{|c|}{11.69} \\
\hline \multirow{2}{*}{$\begin{array}{l}\text { Sign of data63 } \\
\text { Current Income Taxes - Federal } \\
(\mathrm{N}=6,062)\end{array}$} & $\leq 0$ & 39.57 & 0.61 & 37.53 & 2.66 \\
\hline & $>0$ & 15.31 & 44.51 & 8.40 & 51.42 \\
\hline Misclassification & & \multicolumn{2}{|c|}{15.92} & \multicolumn{2}{|c|}{11.06} \\
\hline
\end{tabular}


Table 4

Descriptive Statistics for the Accrual Sample

Panel A: Means and Standard Deviations (6,062 observations)

\begin{tabular}{|l|c|c|}
\hline Variable (Compustat data item) & Mean & Std. Dev. \\
\hline Total Assets (data item 6) & 612.27 & $3,125.30$ \\
\hline Sales (data item 12) & 489.30 & $1,798.83$ \\
\hline $\begin{array}{l}\text { Gross Property, Plant, and Equipment (data } \\
\text { item 7) }\end{array}$ & 424.07 & $1,989.67$ \\
\hline Book Pretax Income (data item 170) & 23.81 & 244.66 \\
\hline Tax Net Income & 15.74 & 165.56 \\
\hline Cash Flows (data item 308 - data item126) & 41.970 & 249.300 \\
\hline Book Total Accruals, scaled (TA ${ }^{\mathrm{F}}$ ) & -0.067 & 0.375 \\
\hline Tax Total Accruals, scaled (TA ${ }^{\mathrm{T}}$ ) & -0.052 & 0.230 \\
\hline
\end{tabular}

Panel B: Pretax Income Correlations ${ }^{1}$

Pretax Book Income
(data170)

Tax Net Income

(LINE28)

Estimated Taxable Income

(GROSS63)

Panel C: Total Accruals Correlations ${ }^{1}$
0.700

Tax Net Income

(LINE28)

0.780

0.670

\section{Book Total Accruals \\ (BOOKTA)}

LINE28TA

GROSS63TA
0.523

0.593
Tax Net Income Total

Accruals

(LINE28TA)

Definitions: Total accruals are defined as either Pretax Book or Tax Net Income less pretax Operating Cash Flows. GROss63 federal income taxes grossed-up by the statutory tax rate, line28 tax net income (net income before net operating loss deduction and special deductions). BOOKTA is scaled total accruals derived from firms' 10-Ks, LINE28TA and GROSS63TA are scaled total accruals for Tax Net Income and Estimated Taxable Income, respectively.

${ }^{1}$ Correlations between pretax book income and tax net income are for 6,062 observations, 5,392 for grossed-up federal income taxes; all correlations are significant at $1 \%$. 
Table 5

Correlation of Accruals Residuals, Pooled and by Industry

(Standard deviations in parentheses)

\begin{tabular}{|c|c|c|c|c|c|}
\hline \multirow[b]{2}{*}{ Mnemonic } & \multirow[b]{2}{*}{ Industry } & \multirow[b]{2}{*}{ SIC } & \multirow[b]{2}{*}{ Observations } & \multicolumn{2}{|c|}{$\begin{array}{l}\text { Correlation matrix of residuals from } \\
\text { the total accruals regressions }\end{array}$} \\
\hline & & & & $\begin{array}{c}\text { System } 1 \\
\text { Book Income } \\
\text { and Tax Net } \\
\text { Income }\end{array}$ & $\begin{array}{c}\text { System } 2 \\
\text { Book Income and } \\
\text { Grossed-up } \\
\text { Federal Taxes }\end{array}$ \\
\hline All & Complete Sample & & 6,062 & 0.503 & 0.116 \\
\hline Agric & Agriculture, Forestry and Fisheries & $01-09$ & 20 & 0.962 & -0.435 \\
\hline Mineral & Mineral Industries & $10-14$ & 304 & 0.667 & 0.377 \\
\hline Constr & Construction Industries & $15-17$ & 77 & 0.891 & 0.741 \\
\hline Mfg & Manufacturing & 20-39 & 2,638 & 0.625 & 0.584 \\
\hline RegInds & Transportation, Communication, and Utilities & $41-49$ & 766 & 0.603 & 0.696 \\
\hline Whole & Wholesale Trade & $50-51$ & 320 & 0.920 & 0.903 \\
\hline Retail & Retail Trade & $52-59$ & 663 & 0.741 & 0.570 \\
\hline FIRE & Finance, Insurance, and Real Estate & $60-67$ & 226 & 0.870 & 0.665 \\
\hline Service & Service Industries & $70-89$ & 1,028 & 0.647 & 0.443 \\
\hline PubAdm & Public Administration & $91-97$ & 20 & 0.460 & -0.332 \\
\hline
\end{tabular}

A total of 64 2-digit SIC industry regressions were estimated. The correlations in the table are average for the 2-digit SIC estimates within each 1-digit SIC industry. For System 1, all but two of the 2-digit correlations are statistically significant at at least 10 percent (SIC 31 Leather, SIC 47 transportation Services) and only 2 are not significant at at least 0.001. For System 2, all but four of the 2-digit correlations are statistically significant at at least 10 percent (SIC 29 Petroleum, SIC 38 Instruments, SIC 75 Auto Repair, SIC 90 not elsewhere classified) and of the remaining all but 6 are significant at at least 0.001 . 
Table 6

Pearson Correlation Coefficients of Discretionary Accruals Estimates

\begin{tabular}{|c|c|c|c|c|c|}
\hline & & \multicolumn{2}{|c|}{ System 1} & \multicolumn{2}{|c|}{ System 2} \\
\hline & & $\begin{array}{c}\text { BOOKDA } \\
\text { DA }^{\mathrm{F}}\end{array}$ & LINE28DA & $\begin{array}{c}\text { BOOKDA } \\
\left(\mathrm{DA}^{\mathrm{F}}\right)\end{array}$ & GROss63DA \\
\hline \multirow{2}{*}{ System 1} & $\begin{array}{l}\text { BOOKDA } \\
\left(\mathrm{DA}^{\mathrm{F}}\right)\end{array}$ & 1.000 & & & \\
\hline & LINE28DA & $0.472^{* * * *}$ & 1.000 & & \\
\hline \multirow{2}{*}{ System 2} & $\begin{array}{l}\text { BOOKDA } \\
\left(\mathrm{DA}^{\mathrm{F}}\right)\end{array}$ & $0.993^{* * *}$ & $0.466^{* * *}$ & 1.000 & \\
\hline & GROSS63DA & $-0.070^{* * *}$ & $0.072^{* * * *}$ & $0.071^{* * *}$ & 1.000 \\
\hline
\end{tabular}

Variable definitions: BOOKDA is the estimate of book discretionary accruals calculated as the residual of the accruals equation (Equation (6)), LINE28DA is the estimate of taxable income discretionary accruals, defined as the residual of Equation (7) using the matched tax return sample. GROSs63DA is the estimate of tax discretionary accruals defined from the residual of Equation (7) using only financial statement data.

${ }^{* * *}$ Significant at 1 percent. Bold entries are correlations from within the same estimation system sizes 6,062 for System 1, 5226 for remaining. 


\section{Table 7}

The Reflection of Book Discretionary Accruals in Tax Discretionary Accruals, Pooled Sample

$$
\frac{D \hat{A}_{i}^{T}}{A_{i, t-1}}=\alpha_{0}+\alpha_{1}+\beta_{1}\left(\frac{D \hat{A}_{i}^{F}}{A_{i, t-1}}>0\right)+\beta_{2}\left(\frac{D \hat{A}_{i}^{F}}{A_{i, t-1}}<0\right)+\gamma_{1}\left(\frac{D \hat{A}_{i}^{F}}{A_{i, t-1}}>0 * N E G T I\right)+\gamma_{2}\left(\frac{D \hat{A}_{i}^{F}}{A_{i, t-1}}<0 * N E G T I\right)
$$

(2)

\begin{tabular}{|c|c|c|}
\hline & $\begin{array}{l}\text { Matched Tax and } \\
\text { Financial Data }\end{array}$ & $\begin{array}{l}\text { Financial Statement } \\
\text { Only }\end{array}$ \\
\hline$\alpha_{0}$ INTERCEPT & $\begin{array}{l}0.031 * * * \\
(0.008)\end{array}$ & $\begin{array}{l}0.009 * \\
(0.005)\end{array}$ \\
\hline $\begin{array}{l}\alpha_{1} \begin{array}{l}\text { Negative Taxable Income } \\
\text { (NEGTI) }\end{array}\end{array}$ & $\begin{array}{l}-0.098 * * * \\
(0.013)\end{array}$ & $\begin{array}{l}-0.142 * * \\
(0.064)\end{array}$ \\
\hline$\beta_{1} \mathrm{DA}^{\mathrm{F}}>0$ & $\begin{array}{l}0.341 * * * \\
(0.102)\end{array}$ & $\begin{array}{l}0.229 * * * \\
(0.048)\end{array}$ \\
\hline$\beta_{2} \mathrm{DA}^{\mathrm{F}}<0$ & $\begin{array}{l}0.761 * * * \\
(0.119)\end{array}$ & $\begin{array}{l}0.761^{* * *} \\
(0.131)\end{array}$ \\
\hline$\gamma_{1}\left(\mathrm{DA}^{\mathrm{F}}>0\right) *$ NEGTI & $\begin{array}{l}0.552 * * * \\
(0.150)\end{array}$ & $\begin{array}{l}0.839 * * * \\
(0.289)\end{array}$ \\
\hline$\gamma_{2}\left(\mathrm{DA}^{\mathrm{F}}<0\right) *$ NEGTI & $\begin{array}{l}-0.519 * * * \\
(0.147)\end{array}$ & $\begin{array}{l}-1.316^{* *} \\
(0.005)\end{array}$ \\
\hline $\begin{array}{l}\text { Observations } \\
\text { Adjusted R-squared }\end{array}$ & $\begin{array}{l}6,062 \\
0.28\end{array}$ & $\begin{array}{l}5,226 \\
0.04\end{array}$ \\
\hline \multicolumn{3}{|c|}{$\begin{array}{l}\text { Robust standard errors in parentheses } \\
* \text { significant at } 10 \% \text {;* significant at } 5 \% \text {; ** significant at } 1 \%\end{array}$} \\
\hline $\begin{array}{l}\beta_{1}+\gamma_{1} \\
\beta_{2}+\gamma_{2}\end{array}$ & $\begin{array}{l}0.893 \\
0.242\end{array}$ & $\begin{array}{l}1.068 \\
-0.555\end{array}$ \\
\hline $\begin{array}{l}\text { F-tests of coefficients: } \\
\beta_{1}=\beta_{2} \\
\beta_{1}+\gamma_{1}=\beta_{2}+\gamma_{2}\end{array}$ & $\begin{array}{l}5.37 * * \\
17.80^{* * *}\end{array}$ & $\begin{array}{l}13.28 * * * \\
4.89 * *\end{array}$ \\
\hline
\end{tabular}

Variable definitions: NEGTI is a binary variable equal to one if the firms reports (or is inferred to have) negative taxable income in the current year, zero otherwise. $D A^{F}$ is the measure of scaled discretionary accruals for financial reporting income), and is separated into two variables, $\left(\mathrm{DA}^{\mathrm{F}}>0, \mathrm{DA}^{\mathrm{F}}<0\right)$ depending on the sign of the discretionary accrual. $\mathrm{DA}^{\mathrm{F}}$ $>0 *$ NEGTI and $\mathrm{DA}^{\mathrm{F}}<0 *$ NEGTI are interaction terms of the sign of the tax discretionary accrual and tax status. 
Table 8

The Reflection of Book Discretionary Accruals in Tax Discretionary Accruals, Industry Results

$$
\frac{D \hat{A}_{i}^{T}}{A_{i, t-1}}=\alpha_{0}+\alpha_{1}+\beta_{1}\left(\frac{D \hat{A}_{i}^{F}}{A_{i, t-1}}>0\right)+\beta_{2}\left(\frac{D \hat{A}_{i}^{F}}{A_{i, t-1}}<0\right)+\gamma_{1}\left(\frac{D \hat{A}_{i}^{F}}{A_{i, t-1}}>0 * N E G T I\right)+\gamma_{2}\left(\frac{D \hat{A}_{i}^{F}}{A_{i, t-1}}<0 * N E G T I\right)
$$

PANEL A: NON-MANUFACTURING INDUSTRIES

\begin{tabular}{|c|c|c|c|c|c|c|c|c|c|c|}
\hline & $\begin{array}{l}(1) \\
\text { All }\end{array}$ & $\begin{array}{l}(2) \\
\text { Agric }\end{array}$ & $\begin{array}{l}\text { (3) } \\
\text { Mineral }\end{array}$ & $\begin{array}{l}(4) \\
\text { Constr }\end{array}$ & $\begin{array}{l}\text { (5) } \\
\text { RegInds }\end{array}$ & $\begin{array}{l}(6) \\
\text { Whole }\end{array}$ & $\begin{array}{l}(7) \\
\text { Retail }\end{array}$ & $\begin{array}{l}(8) \\
\text { FIRE }\end{array}$ & $\begin{array}{l}(9) \\
\text { Service }\end{array}$ & $\begin{array}{c}(10) \\
\text { PubAdmin }\end{array}$ \\
\hline$\alpha_{0}$ INTERCEPT & $\begin{array}{l}0.032^{* * *} \\
(0.009)\end{array}$ & $\begin{array}{l}-0.001 \\
(0.012)\end{array}$ & $\begin{array}{l}-0.025^{*} \\
(0.014)\end{array}$ & $\begin{array}{l}-0.006 \\
(0.007)\end{array}$ & $\begin{array}{l}-0.010^{* * *} \\
(0.003)\end{array}$ & $\begin{array}{l}0.006 \\
(0.008)\end{array}$ & $\begin{array}{l}0.000 \\
(0.006)\end{array}$ & $\begin{array}{l}0.017 * * \\
(0.007)\end{array}$ & $\begin{array}{l}0.046^{* * *} \\
(0.007)\end{array}$ & $\begin{array}{l}0.104 \\
(0.113)\end{array}$ \\
\hline $\begin{array}{l}\alpha_{1} \begin{array}{l}\text { Negative Taxable Income } \\
\text { (NEGTI) }\end{array}\end{array}$ & $\begin{array}{l}-0.086^{* * *} \\
(0.016)\end{array}$ & $\begin{array}{l}-0.026 \\
(0.016)\end{array}$ & $\begin{array}{l}0.004 \\
(0.020)\end{array}$ & $\begin{array}{l}-0.010 \\
(0.015)\end{array}$ & $\begin{array}{l}0.039 * * * \\
(0.011)\end{array}$ & $\begin{array}{l}-0.005 \\
(0.017)\end{array}$ & $\begin{array}{l}-0.028 \\
(0.020)\end{array}$ & $\begin{array}{l}-0.023 \\
(0.017)\end{array}$ & $\begin{array}{l}-0.132 * * * \\
(0.022)\end{array}$ & $\begin{array}{l}-0.158 \\
(0.129)\end{array}$ \\
\hline$\beta_{1}$ ВООК28DA $>0$ & $\begin{array}{l}0.348^{* * *} \\
(0.122)\end{array}$ & $\begin{array}{l}1.018^{* * *} \\
(0.095)\end{array}$ & $\begin{array}{l}0.843^{* * *} \\
(0.118)\end{array}$ & $\begin{array}{l}0.917 * * * \\
(0.042)\end{array}$ & $\begin{array}{l}0.985^{* * *} \\
(0.073)\end{array}$ & $\begin{array}{l}1.034^{* * *} \\
(0.112)\end{array}$ & $\begin{array}{l}0.753^{* * *} \\
(0.145)\end{array}$ & $\begin{array}{l}0.918^{* * *} \\
(0.046)\end{array}$ & $\begin{array}{l}0.230 * * * \\
(0.041)\end{array}$ & $\begin{array}{r}0.353^{* * *} \\
(0.099)\end{array}$ \\
\hline$\beta_{2}$ ВООК28DA $<0$ & $\begin{array}{l}1.042^{* * *} \\
(0.104)\end{array}$ & $\begin{array}{l}0.540 * * * \\
(0.162)\end{array}$ & $\begin{array}{l}0.203 \\
(0.159)\end{array}$ & $\begin{array}{l}1.012 * * * \\
(0.140)\end{array}$ & $\begin{array}{l}0.361^{* * *} \\
(0.128)\end{array}$ & $\begin{array}{l}1.161^{* * *} \\
(0.085)\end{array}$ & $\begin{array}{l}0.735^{* * *} \\
(0.087)\end{array}$ & $\begin{array}{l}1.050 * * * \\
(0.166)\end{array}$ & $\begin{array}{l}1.190 * * * \\
(0.251)\end{array}$ & $\begin{array}{l}0.068 \\
(0.192)\end{array}$ \\
\hline$\gamma_{1}($ BOOK28DA $>0) *$ NEGTI & $\begin{array}{l}0.578 * * * \\
(0.204)\end{array}$ & $\begin{array}{l}-0.316 * \\
(0.168)\end{array}$ & $\begin{array}{l}-0.371^{* *} \\
(0.180)\end{array}$ & $\begin{array}{l}-0.730 * * * \\
(0.250)\end{array}$ & $\begin{array}{l}-0.655^{* * *} \\
(0.173)\end{array}$ & $\begin{array}{l}-0.096 \\
(0.204)\end{array}$ & $\begin{array}{l}-0.107 \\
(0.217)\end{array}$ & $\begin{array}{l}-0.044 \\
(0.078)\end{array}$ & $\begin{array}{l}0.882 * * * \\
(0.225)\end{array}$ & $\begin{array}{l}-0.186 \\
(0.113)\end{array}$ \\
\hline$\gamma_{2}($ BOOK28DA $<0) *$ NEGTI & $\begin{array}{l}-0.705^{* * *} \\
(0.148)\end{array}$ & $\begin{array}{l}0.115 \\
(0.277)\end{array}$ & $\begin{array}{l}0.185 \\
(0.180)\end{array}$ & $\begin{array}{l}-0.492^{* *} \\
(0.195)\end{array}$ & $\begin{array}{l}0.664 * * * \\
(0.153)\end{array}$ & $\begin{array}{l}-0.107 \\
(0.133)\end{array}$ & $\begin{array}{l}-0.382 \\
(0.278)\end{array}$ & $\begin{array}{l}-0.073 \\
(0.188)\end{array}$ & $\begin{array}{l}-0.958^{* * * *} \\
(0.270)\end{array}$ & $\begin{array}{l}0.000 \\
(0.000)\end{array}$ \\
\hline $\begin{array}{l}\text { Observations } \\
\text { Adjusted R-squared }\end{array}$ & $\begin{array}{l}3424 \\
0.39\end{array}$ & $\begin{array}{l}20 \\
0.93\end{array}$ & $\begin{array}{l}304 \\
0.42\end{array}$ & $\begin{array}{l}77 \\
0.81\end{array}$ & $\begin{array}{l}766 \\
0.85\end{array}$ & $\begin{array}{l}320 \\
0.87\end{array}$ & $\begin{array}{l}663 \\
0.48\end{array}$ & $\begin{array}{l}226 \\
0.77\end{array}$ & $\begin{array}{l}1028 \\
0.34\end{array}$ & $\begin{array}{l}20 \\
0.18\end{array}$ \\
\hline $\begin{array}{l}\beta_{1}+\gamma_{1} \\
\beta_{2}+\gamma_{2}\end{array}$ & $\begin{array}{l}0.926 \\
0.337\end{array}$ & $\begin{array}{l}0.702 \\
0.655\end{array}$ & $\begin{array}{l}0.472 \\
0.388\end{array}$ & $\begin{array}{l}0.187 \\
0.520\end{array}$ & $\begin{array}{l}0.330 \\
1.025\end{array}$ & $\begin{array}{l}0.938 \\
1.054\end{array}$ & $\begin{array}{l}0.646 \\
0.353\end{array}$ & $\begin{array}{l}0.874 \\
0.977\end{array}$ & $\begin{array}{l}1.112 \\
0.232\end{array}$ & $\begin{array}{l}0.167 \\
0.068\end{array}$ \\
\hline $\begin{array}{l}\text { F-tests of coefficients: } \\
\beta_{1}=\beta_{2} \\
\beta_{1}+\gamma_{1}=\beta_{2}+\gamma_{2}\end{array}$ & $\begin{array}{l}12.11^{* * *} \\
7.97 * * *\end{array}$ & $\begin{array}{l}5.32 * * \\
0.02\end{array}$ & $\begin{array}{l}7.56^{* * *} \\
0.19\end{array}$ & $\begin{array}{l}0.41 \\
1.05\end{array}$ & $\begin{array}{l}15.53^{* * *} \\
13.71^{* * *}\end{array}$ & $\begin{array}{l}0.59 \\
0.29\end{array}$ & $\begin{array}{l}0.01 \\
0.52\end{array}$ & $\begin{array}{l}0.49 \\
0.87\end{array}$ & $\begin{array}{l}13.54 * * * \\
12.08 * * *\end{array}$ & $\begin{array}{l}1.74 \\
0.21\end{array}$ \\
\hline
\end{tabular}


PANEL B: MANUFACTURING INDUSTRIES, SIC 2000 - 2999

\begin{tabular}{|c|c|c|c|c|c|c|c|c|c|c|}
\hline um & $\begin{array}{l}(1) \\
\text { All }\end{array}$ & $\begin{array}{l}\text { (2) } \\
\text { Food }\end{array}$ & $\begin{array}{l}\text { (3) } \\
\text { Textile }\end{array}$ & $\begin{array}{l}\text { (4) } \\
\text { Apparel }\end{array}$ & $\begin{array}{l}\text { (5) } \\
\text { Lumber }\end{array}$ & $\begin{array}{l}\text { (6) } \\
\text { Furniture }\end{array}$ & $\begin{array}{l}(7) \\
\text { Paper }\end{array}$ & $\begin{array}{l}(8) \\
\text { Printing }\end{array}$ & $\begin{array}{l}\text { (9) } \\
\text { Chemicals }\end{array}$ & $\begin{array}{l}(10) \\
\text { Petrole }\end{array}$ \\
\hline$\alpha_{0}$ INTERCEPT & $\begin{array}{l}0.035^{* *} \\
(0.014)\end{array}$ & $\begin{array}{l}0.004 \\
(0.005)\end{array}$ & $\begin{array}{l}0.013^{*} \\
(0.007)\end{array}$ & $\begin{array}{l}-0.002 \\
(0.006)\end{array}$ & $\begin{array}{l}-0.008 \\
(0.012)\end{array}$ & $\begin{array}{l}0.005 \\
(0.011)\end{array}$ & $\begin{array}{l}-0.027^{*} \\
(0.016)\end{array}$ & $\begin{array}{l}0.008^{*} \\
(0.004)\end{array}$ & $\begin{array}{l}0.002 \\
(0.025)\end{array}$ & $\begin{array}{l}-0.016 \\
(0.012)\end{array}$ \\
\hline $\begin{array}{l}\alpha_{1} \text { Negative Taxable Income } \\
\text { (NEGTI) }\end{array}$ & $\begin{array}{l}-0.120 * * * \\
(0.018)\end{array}$ & $\begin{array}{l}-0.110 \\
(0.076)\end{array}$ & $\begin{array}{l}-0.022 * \\
(0.013)\end{array}$ & $\begin{array}{l}-0.001 \\
(0.037)\end{array}$ & $\begin{array}{l}-0.047 * * * \\
(0.012)\end{array}$ & $\begin{array}{l}-0.117^{* *} \\
(0.045)\end{array}$ & $\begin{array}{l}0.022 \\
(0.027)\end{array}$ & $\begin{array}{l}-0.035 \\
(0.051)\end{array}$ & $\begin{array}{l}-0.077^{* *} \\
(0.034)\end{array}$ & $\begin{array}{l}-0.005 \\
(0.041)\end{array}$ \\
\hline$\beta_{1}$ BOOK28DA $>0$ & $\begin{array}{l}0.314^{*} \\
(0.190)\end{array}$ & $\begin{array}{l}0.844 * * * \\
(0.028)\end{array}$ & $\begin{array}{l}0.682 * * * \\
(0.115)\end{array}$ & $\begin{array}{l}1.073^{* * *} \\
(0.100)\end{array}$ & $\begin{array}{l}0.965 * * * \\
(0.188)\end{array}$ & $\begin{array}{l}0.984 * * * \\
(0.135)\end{array}$ & $\begin{array}{l}0.613 * * * \\
(0.159)\end{array}$ & $\begin{array}{l}0.892 * * * \\
(0.122)\end{array}$ & $\begin{array}{l}0.879 * * * \\
(0.126)\end{array}$ & $\begin{array}{r}1.054^{* * *} \\
(0.327)\end{array}$ \\
\hline$\beta_{2}$ BOOK28DA $<0$ & $\begin{array}{l}0.571^{* * *} \\
(0.124)\end{array}$ & $\begin{array}{l}0.513 * * * \\
(0.147)\end{array}$ & $\begin{array}{l}0.804 * * \\
(0.334)\end{array}$ & $\begin{array}{l}0.839 * * * \\
(0.085)\end{array}$ & $\begin{array}{l}0.620^{* *} \\
(0.231)\end{array}$ & $\begin{array}{l}1.254^{* * *} \\
(0.291)\end{array}$ & $\begin{array}{l}-0.256 \\
(0.277)\end{array}$ & $\begin{array}{l}0.875^{* * *} \\
(0.023)\end{array}$ & $\begin{array}{l}0.379 * * * \\
(0.092)\end{array}$ & $\begin{array}{r}0.707^{* * *} \\
(0.149)\end{array}$ \\
\hline$\gamma_{1}($ BOOK28DA $>0) *$ NEGTI & $\begin{array}{l}0.558^{* *} \\
(0.229)\end{array}$ & $\begin{array}{l}-0.293^{*} \\
(0.151)\end{array}$ & $\begin{array}{l}0.280 \\
(0.168)\end{array}$ & $\begin{array}{l}0.096 \\
(0.230)\end{array}$ & $\begin{array}{l}0.009 \\
(0.188)\end{array}$ & $\begin{array}{l}1.820 * * * \\
(0.593)\end{array}$ & $\begin{array}{l}-0.461^{* *} \\
(0.225)\end{array}$ & $\begin{array}{l}-1.876 \\
(1.139)\end{array}$ & $\begin{array}{l}-0.228 \\
(0.310)\end{array}$ & $\begin{array}{l}-1.060 \\
(1.107)\end{array}$ \\
\hline$\gamma_{2}($ BOOK28DA $<0) *$ NEGTI & $\begin{array}{l}-0.482 * * * \\
(0.140)\end{array}$ & $\begin{array}{l}-0.417 \\
(0.359)\end{array}$ & $\begin{array}{l}0.106 \\
(0.350)\end{array}$ & $\begin{array}{l}0.435^{*} \\
(0.227)\end{array}$ & $\begin{array}{l}-0.414^{*} \\
(0.231)\end{array}$ & $\begin{array}{l}-1.186^{* * *} \\
(0.421)\end{array}$ & $\begin{array}{l}0.649 * \\
(0.325)\end{array}$ & $\begin{array}{l}-0.936 \\
(0.570)\end{array}$ & $\begin{array}{l}-0.352 * * * \\
(0.098)\end{array}$ & $\begin{array}{r}-0.937 * * \\
(0.365)\end{array}$ \\
\hline $\begin{array}{l}\text { Observations } \\
\text { Adjusted R-squared }\end{array}$ & $\begin{array}{l}2638 \\
0.18\end{array}$ & $\begin{array}{l}170 \\
0.27\end{array}$ & $\begin{array}{l}44 \\
0.87\end{array}$ & $\begin{array}{l}55 \\
0.92\end{array}$ & $\begin{array}{l}31 \\
0.69\end{array}$ & $\begin{array}{l}32 \\
0.84\end{array}$ & $\begin{array}{l}68 \\
0.31\end{array}$ & $\begin{array}{l}96 \\
0.42\end{array}$ & $\begin{array}{l}630 \\
0.13\end{array}$ & $\begin{array}{l}32 \\
0.25\end{array}$ \\
\hline $\begin{array}{l}\beta_{1}+\gamma_{1} \\
\beta_{2}+\gamma_{2}\end{array}$ & $\begin{array}{l}0.872 \\
0.089\end{array}$ & $\begin{array}{l}0.551 \\
0.096\end{array}$ & $\begin{array}{l}0.962 \\
0.910\end{array}$ & $\begin{array}{l}1.169 \\
1.274\end{array}$ & $\begin{array}{l}0.974 \\
0.206\end{array}$ & $\begin{array}{l}2.804 \\
0.068\end{array}$ & $\begin{array}{l}0.152 \\
0.393\end{array}$ & $\begin{array}{l}-0.984 \\
-0.061\end{array}$ & $\begin{array}{l}0.651 \\
0.027\end{array}$ & $\begin{array}{l}-0.006 \\
-0.230\end{array}$ \\
\hline $\begin{array}{l}\text { F-tests of coefficients: } \\
\beta_{1}=\beta_{2} \\
\beta_{1}+\gamma_{1}=\beta_{2}+\gamma_{2}\end{array}$ & $\begin{array}{l}0.92 \\
26.55 * * *\end{array}$ & $\begin{array}{l}4.34^{* *} \\
1.19\end{array}$ & $\begin{array}{l}0.11 \\
0.07\end{array}$ & $\begin{array}{l}2.42 \\
0.07\end{array}$ & $\begin{array}{l}0.85 \\
21.16^{* * *}\end{array}$ & $\begin{array}{l}0.50 \\
10.08 * * *\end{array}$ & $\begin{array}{l}4.81^{* *} \\
0.90\end{array}$ & $\begin{array}{l}0.02 \\
0.45\end{array}$ & $\begin{array}{l}7.80 * * * \\
4.59 * *\end{array}$ & $\begin{array}{l}0.61 \\
0.03\end{array}$ \\
\hline
\end{tabular}


PANEL C: MANUFACTURING INDUSTRIES, SIC 3000 - 3999

\begin{tabular}{|c|c|c|c|c|c|c|c|c|c|c|}
\hline & $\begin{array}{l}(1) \\
\text { Rubber }\end{array}$ & $\begin{array}{l}(2) \\
\text { Leather }\end{array}$ & $\begin{array}{l}\text { (3) } \\
\text { Stone }\end{array}$ & $\begin{array}{l}(4) \\
\text { Primary }\end{array}$ & $\begin{array}{l}\text { (5) } \\
\text { Fabricated } \\
\text { Mfg }\end{array}$ & $\begin{array}{l}\text { (6) } \\
\text { Industrial }\end{array}$ & $\begin{array}{l}(7) \\
\text { Electrical }\end{array}$ & $\begin{array}{l}\text { (8) } \\
\text { Transportation }\end{array}$ & $\begin{array}{l}\text { (9) } \\
\text { Instruments }\end{array}$ & $\begin{array}{l}\text { (10) } \\
\text { Misc }\end{array}$ \\
\hline & & & & Metals & Metals & Machinery & Equipment & Equipment & & \\
\hline$\alpha_{0}$ INTERCEPT & $\begin{array}{l}0.003 \\
(0.008)\end{array}$ & $\begin{array}{l}-0.018 \\
(0.050)\end{array}$ & $\begin{array}{l}-0.003 \\
(0.006)\end{array}$ & $\begin{array}{l}-0.008 \\
(0.006)\end{array}$ & $\begin{array}{l}-0.001 \\
(0.006)\end{array}$ & $\begin{array}{l}-0.025^{*} \\
(0.015)\end{array}$ & $\begin{array}{l}0.046^{* * *} \\
(0.010)\end{array}$ & $\begin{array}{l}-0.011^{*} \\
(0.006)\end{array}$ & $\begin{array}{l}-0.027^{* *} \\
(0.010)\end{array}$ & $\begin{array}{l}0.000 \\
(0.009)\end{array}$ \\
\hline $\begin{array}{l}\alpha_{1} \text { Negative Taxable Income } \\
\text { (NEGTI) }\end{array}$ & $\begin{array}{l}-0.003 \\
(0.014)\end{array}$ & $\begin{array}{l}-0.171^{* *} \\
(0.071)\end{array}$ & $\begin{array}{l}-0.036 \\
(0.047)\end{array}$ & $\begin{array}{l}-0.017 \\
(0.013)\end{array}$ & $\begin{array}{l}-0.019 * \\
(0.011)\end{array}$ & $\begin{array}{l}0.007 \\
(0.030)\end{array}$ & $\begin{array}{l}-0.108 * * \\
(0.049)\end{array}$ & $\begin{array}{l}0.023 * \\
(0.014)\end{array}$ & $\begin{array}{l}-0.056^{* *} \\
(0.024)\end{array}$ & $\begin{array}{l}0.019 \\
(0.023)\end{array}$ \\
\hline$\beta_{1}$ BОOK28DA $>0$ & $\begin{array}{l}0.976 * * * \\
(0.178)\end{array}$ & $\begin{array}{l}0.039 \\
(0.931)\end{array}$ & $\begin{array}{l}1.107 * * * \\
(0.121)\end{array}$ & $\begin{array}{l}0.886 * * * \\
(0.054)\end{array}$ & $\begin{array}{l}0.977 * * * \\
(0.080)\end{array}$ & $\begin{array}{l}1.042 * * * \\
(0.103)\end{array}$ & $\begin{array}{l}0.109 * \\
(0.057)\end{array}$ & $\begin{array}{l}1.022 * * * \\
(0.055)\end{array}$ & $\begin{array}{l}1.006 * * * \\
(0.121)\end{array}$ & $\begin{array}{r}0.932 * * * \\
(0.080)\end{array}$ \\
\hline$\beta_{2}$ BООK28DA $<0$ & $\begin{array}{l}0.995 * * * \\
(0.140)\end{array}$ & $\begin{array}{l}-0.875 \\
(0.938)\end{array}$ & $\begin{array}{l}0.875^{* * *} \\
(0.120)\end{array}$ & $\begin{array}{l}0.475^{* *} \\
(0.207)\end{array}$ & $\begin{array}{l}0.882 * * * \\
(0.106)\end{array}$ & $\begin{array}{l}0.116^{*} \\
(0.068)\end{array}$ & $\begin{array}{l}0.499 * * * \\
(0.163)\end{array}$ & $\begin{array}{l}0.691 * * * \\
(0.121)\end{array}$ & $\begin{array}{l}0.289 \\
(0.190)\end{array}$ & $\begin{array}{r}0.890 * * * \\
(0.231)\end{array}$ \\
\hline$\gamma_{1}($ BOOK28DA $>0) *$ NEGTI & $\begin{array}{l}-0.176 \\
(0.221)\end{array}$ & $\begin{array}{l}0.000 \\
(0.000)\end{array}$ & $\begin{array}{l}0.000 \\
(0.000)\end{array}$ & $\begin{array}{l}-0.005 \\
(0.295)\end{array}$ & $\begin{array}{l}-0.255 \\
(0.255)\end{array}$ & $\begin{array}{l}-0.031 \\
(0.107)\end{array}$ & $\begin{array}{l}0.957 * * * \\
(0.180)\end{array}$ & $\begin{array}{l}-3.199 * * * \\
(0.985)\end{array}$ & $\begin{array}{l}-0.105 \\
(0.255)\end{array}$ & $\begin{array}{l}-1.028 \\
(0.715)\end{array}$ \\
\hline$\gamma_{2}($ BOOK28DA $<0) *$ NEGTI & $\begin{array}{l}0.037 \\
(0.154)\end{array}$ & $\begin{array}{l}0.000 \\
(0.000)\end{array}$ & $\begin{array}{l}-0.408 \\
(0.522)\end{array}$ & $\begin{array}{l}-0.056 \\
(0.232)\end{array}$ & $\begin{array}{l}-0.155 \\
(0.177)\end{array}$ & $\begin{array}{l}0.759 * * * \\
(0.119)\end{array}$ & $\begin{array}{l}-0.114 \\
(0.421)\end{array}$ & $\begin{array}{l}0.273 * \\
(0.159)\end{array}$ & $\begin{array}{l}-0.251 \\
(0.205)\end{array}$ & $\begin{array}{l}0.115 \\
(0.320)\end{array}$ \\
\hline $\begin{array}{l}\text { Observations } \\
\text { Adjusted R-squared }\end{array}$ & $\begin{array}{l}63 \\
0.83\end{array}$ & $\begin{array}{l}13 \\
0.00\end{array}$ & $\begin{array}{l}37 \\
0.80\end{array}$ & $\begin{array}{l}139 \\
0.68\end{array}$ & $\begin{array}{l}74 \\
0.89\end{array}$ & $\begin{array}{l}254 \\
0.64\end{array}$ & $\begin{array}{l}443 \\
0.17\end{array}$ & $\begin{array}{l}103 \\
0.87\end{array}$ & $\begin{array}{l}296 \\
0.18\end{array}$ & $\begin{array}{l}58 \\
0.76\end{array}$ \\
\hline $\begin{array}{l}\beta_{1}+\gamma_{1} \\
\beta_{2}+\gamma_{2}\end{array}$ & $\begin{array}{l}0.800 \\
1.032\end{array}$ & $\begin{array}{l}0.039 \\
-0.875\end{array}$ & $\begin{array}{l}1.107 \\
0.467\end{array}$ & $\begin{array}{l}0.881 \\
0.419\end{array}$ & $\begin{array}{l}0.722 \\
0.727\end{array}$ & $\begin{array}{l}1.011 \\
0.875\end{array}$ & $\begin{array}{l}1.066 \\
0.385\end{array}$ & $\begin{array}{l}-2.177 \\
0.964\end{array}$ & $\begin{array}{l}0.901 \\
0.038\end{array}$ & $\begin{array}{l}-0.096 \\
1.005\end{array}$ \\
\hline $\begin{array}{l}\text { F-tests of coefficients: } \\
\beta_{1}=\beta_{2} \\
\beta_{1}+\gamma_{1}=\beta_{2}+\gamma_{2}\end{array}$ & $\begin{array}{l}0.01 \\
2.05\end{array}$ & $\begin{array}{l}0.31 \\
0.31\end{array}$ & $\begin{array}{l}1.37 \\
1.50\end{array}$ & $\begin{array}{l}2.84^{*} \\
1.82\end{array}$ & $\begin{array}{l}0.33 \\
0.00\end{array}$ & $\begin{array}{l}39.72 * * * \\
1.42\end{array}$ & $\begin{array}{l}4.83^{* *} \\
2.03\end{array}$ & $\begin{array}{l}4.92 * * \\
9.66 * * *\end{array}$ & $\begin{array}{l}7.82^{* * *} \\
12.35^{* * *}\end{array}$ & $\begin{array}{l}0.03 \\
1.76\end{array}$ \\
\hline
\end{tabular}

Robust standard errors in parentheses

* significant at $10 \%$; ** significant at $5 \%$; *** significant at $1 \%$

See Table 7 for a description of the variables. 
Table 9

The Reflection of Book Discretionary Accruals in Tax Discretionary Accruals - Financial Statement Measures

$$
\frac{D \hat{A}_{i}^{T}}{A_{i, t-1}}=\alpha_{0}+\alpha_{1}+\beta_{1}\left(\frac{D \hat{A}_{i}^{F}}{A_{i, t-1}}>0\right)+\beta_{2}\left(\frac{D \hat{A}_{i}^{F}}{A_{i, t-1}}<0\right)+\gamma_{1}\left(\frac{D \hat{A}_{i}^{F}}{A_{i, t-1}}>0 * N E G T I\right)+\gamma_{2}\left(\frac{D \hat{A}_{i}^{F}}{A_{i, t-1}}<0 * N E G T I\right)
$$

PANEL A: NON-MANUFACTURING INDUSTRIES

\begin{tabular}{|c|c|c|c|c|c|c|c|c|c|c|}
\hline & $\begin{array}{l}(1) \\
\text { All }\end{array}$ & $\begin{array}{l}(2) \\
\text { Agric }\end{array}$ & $\begin{array}{l}\text { (3) } \\
\text { Mineral }\end{array}$ & $\begin{array}{l}\text { (4) } \\
\text { Constr }\end{array}$ & $\begin{array}{l}\text { (5) } \\
\text { RegInds }\end{array}$ & $\begin{array}{l}\text { (6) } \\
\text { Whole }\end{array}$ & $\begin{array}{l}\text { (7) } \\
\text { Retail }\end{array}$ & $\begin{array}{l}(8) \\
\text { FIRE }\end{array}$ & $\begin{array}{l}(9) \\
\text { Service }\end{array}$ & $\begin{array}{c}\text { (10) } \\
\text { PubAdmin }\end{array}$ \\
\hline$\overline{\alpha_{0}}$ INTERCEPT & $\begin{array}{l}0.009^{* *} \\
(0.004)\end{array}$ & $\begin{array}{l}0.033 \\
(0.032)\end{array}$ & $\begin{array}{l}-0.058 * * \\
(0.028)\end{array}$ & $\begin{array}{l}-0.011 \\
(0.010)\end{array}$ & $\begin{array}{l}-0.003 \\
(0.003)\end{array}$ & $\begin{array}{l}-0.004 \\
(0.006)\end{array}$ & $\begin{array}{l}-0.013^{* * *} \\
(0.004)\end{array}$ & $\begin{array}{l}0.026^{*} \\
(0.014)\end{array}$ & $\begin{array}{l}-0.003 \\
(0.012)\end{array}$ & $\begin{array}{l}-0.268^{* * *} \\
(0.000)\end{array}$ \\
\hline $\begin{array}{l}\alpha_{1} \text { Negative Taxable Income } \\
\text { (NEGTI) }\end{array}$ & $\begin{array}{l}-0.061^{* * *} \\
(0.022)\end{array}$ & $\begin{array}{l}-0.009 \\
(0.046)\end{array}$ & $\begin{array}{l}0.074 * * \\
(0.034)\end{array}$ & $\begin{array}{l}-0.015 \\
(0.018)\end{array}$ & $\begin{array}{l}0.013 \\
(0.012)\end{array}$ & $\begin{array}{l}-0.005 \\
(0.015)\end{array}$ & $\begin{array}{l}0.003 \\
(0.016)\end{array}$ & $\begin{array}{l}-0.081 \\
(0.076)\end{array}$ & $\begin{array}{l}-0.080 \\
(0.054)\end{array}$ & $\begin{array}{l}0.094 \\
(0.118)\end{array}$ \\
\hline$\beta_{1}$ ВООК63DA $>0$ & $\begin{array}{l}0.243^{* * *} \\
(0.038)\end{array}$ & $\begin{array}{l}-1.012 \\
(0.775)\end{array}$ & $\begin{array}{l}0.665^{* * *} \\
(0.221)\end{array}$ & $\begin{array}{l}0.883 * * * \\
(0.078)\end{array}$ & $\begin{array}{l}0.444 * * * \\
(0.081)\end{array}$ & $\begin{array}{l}0.815^{* * *} \\
(0.085)\end{array}$ & $\begin{array}{l}0.790 * * * \\
(0.060)\end{array}$ & $\begin{array}{l}0.858 * * * \\
(0.105)\end{array}$ & $\begin{array}{l}0.200 * * * \\
(0.009)\end{array}$ & $\begin{array}{l}0.056^{* * *} \\
(0.000)\end{array}$ \\
\hline$\beta_{2}$ BOOK63DA $<0$ & $\begin{array}{l}1.028 * * * \\
(0.136)\end{array}$ & $\begin{array}{l}0.609 * \\
(0.327)\end{array}$ & $\begin{array}{l}1.391^{* * *} \\
(0.530)\end{array}$ & $\begin{array}{l}1.039 * * * \\
(0.208)\end{array}$ & $\begin{array}{l}0.731^{* * *} \\
(0.130)\end{array}$ & $\begin{array}{l}0.737 * * * \\
(0.082)\end{array}$ & $\begin{array}{l}0.668 * * * \\
(0.074)\end{array}$ & $\begin{array}{l}0.988 * * * \\
(0.113)\end{array}$ & $\begin{array}{l}1.643^{* * * *} \\
(0.419)\end{array}$ & $\begin{array}{r}-19.102 * * * \\
(0.000)\end{array}$ \\
\hline$\gamma_{1}$ BOOK63DA $>0 *$ NEGTI & $\begin{array}{l}0.738^{* *} \\
(0.352)\end{array}$ & $\begin{array}{l}0.406 \\
(0.880)\end{array}$ & $\begin{array}{l}-0.103 \\
(0.275)\end{array}$ & $\begin{array}{l}0.010 \\
(0.172)\end{array}$ & $\begin{array}{l}0.052 \\
(0.110)\end{array}$ & $\begin{array}{l}-0.149 \\
(0.101)\end{array}$ & $\begin{array}{l}-0.161 \\
(0.306)\end{array}$ & $\begin{array}{l}0.175 \\
(0.140)\end{array}$ & $\begin{array}{l}1.056^{*} \\
(0.564)\end{array}$ & $\begin{array}{l}-0.049 \\
(0.103)\end{array}$ \\
\hline$\gamma_{2}$ BOOK63DA $<0 *$ NEGTI & $\begin{array}{l}-0.982 * * * \\
(0.152)\end{array}$ & $\begin{array}{l}-1.112 \\
(0.654)\end{array}$ & $\begin{array}{l}-1.124^{* *} \\
(0.552)\end{array}$ & $\begin{array}{l}-0.722 * * * \\
(0.226)\end{array}$ & $\begin{array}{l}-0.305^{* *} \\
(0.146)\end{array}$ & $\begin{array}{l}-0.067 \\
(0.104)\end{array}$ & $\begin{array}{l}-0.432 * * \\
(0.210)\end{array}$ & $\begin{array}{l}-0.300 \\
(0.234)\end{array}$ & $\begin{array}{l}-1.655 * * * \\
(0.424)\end{array}$ & $\begin{array}{r}18.385^{* * * *} \\
(0.718)\end{array}$ \\
\hline $\begin{array}{l}\text { Observations } \\
\text { Adjusted R-squared } \\
\end{array}$ & $\begin{array}{l}2913 \\
0.06 \\
\end{array}$ & $\begin{array}{l}16 \\
-0.06 \\
\end{array}$ & $\begin{array}{l}221 \\
0.24 \\
\end{array}$ & $\begin{array}{l}68 \\
0.67 \\
\end{array}$ & $\begin{array}{l}696 \\
0.49 \\
\end{array}$ & $\begin{array}{l}270 \\
0.80 \\
\end{array}$ & $\begin{array}{l}563 \\
0.28 \\
\end{array}$ & $\begin{array}{l}175 \\
0.28 \\
\end{array}$ & $\begin{array}{l}884 \\
0.05 \\
\end{array}$ & $\begin{array}{l}20 \\
0.13 \\
\end{array}$ \\
\hline $\begin{array}{l}\beta_{1}+\gamma_{1} \\
\beta_{2}+\gamma_{2}\end{array}$ & $\begin{array}{l}0.981 \\
0.046\end{array}$ & $\begin{array}{l}-0.606 \\
-0.503\end{array}$ & $\begin{array}{l}0.562 \\
0.267\end{array}$ & $\begin{array}{l}0.893 \\
0.317\end{array}$ & $\begin{array}{l}0.496 \\
0.426\end{array}$ & $\begin{array}{l}0.666 \\
0.670\end{array}$ & $\begin{array}{l}0.629 \\
0.236\end{array}$ & $\begin{array}{l}1.033 \\
0.688\end{array}$ & $\begin{array}{l}1.256 \\
-0.012\end{array}$ & $\begin{array}{l}0.007 \\
-0.717\end{array}$ \\
\hline $\begin{array}{l}\text { F-tests of coefficients: } \\
\beta_{1}=\beta_{2} \\
\beta_{1}+\gamma_{1}=\beta_{2}+\gamma_{2}\end{array}$ & $\begin{array}{l}28.74 * * * \\
6.69 * * *\end{array}$ & $\begin{array}{l}2.39 \\
0.04\end{array}$ & $\begin{array}{l}1.41 \\
1.12\end{array}$ & $\begin{array}{l}0.44 \\
9.26^{* * *}\end{array}$ & $\begin{array}{l}2.93 * \\
0.46\end{array}$ & $\begin{array}{l}0.34 \\
0.00\end{array}$ & $\begin{array}{l}1.28 \\
0.96\end{array}$ & $\begin{array}{l}0.54 \\
1.60\end{array}$ & $\begin{array}{l}11.71 * * * \\
4.91^{* *}\end{array}$ & 0.92 \\
\hline
\end{tabular}


PANEL B: MANUFACTURING INDUSTRIES, SIC 2000 - 2999

\begin{tabular}{|c|c|c|c|c|c|c|c|c|c|c|}
\hline & $\begin{array}{l}\text { (1) } \\
\text { All }\end{array}$ & $\begin{array}{l}(2) \\
\text { Food }\end{array}$ & $\begin{array}{l}\text { (3) } \\
\text { Textile }\end{array}$ & $\begin{array}{l}\text { (4) } \\
\text { Apparel }\end{array}$ & $\begin{array}{l}\text { L) } \\
\text { Lumber }\end{array}$ & $\begin{array}{l}\text { (6) } \\
\text { Furniture }\end{array}$ & $\begin{array}{l}\text { (7) } \\
\text { Paper }\end{array}$ & $\begin{array}{l}\text { (8) } \\
\text { Printing }\end{array}$ & $\begin{array}{l}\text { (9) } \\
\text { Chemicals }\end{array}$ & $\begin{array}{l}(10) \\
\text { Petroleum }\end{array}$ \\
\hline$\overline{\alpha_{0} \text { INTERCEPT }}$ & $\begin{array}{l}0.013 \\
(0.010)\end{array}$ & $\begin{array}{l}0.012 \\
(0.012)\end{array}$ & $\begin{array}{l}0.006 \\
(0.008)\end{array}$ & $\begin{array}{l}0.199 * * * \\
(0.065)\end{array}$ & $\begin{array}{l}0.004 \\
(0.006)\end{array}$ & $\begin{array}{l}0.001 \\
(0.007)\end{array}$ & $\begin{array}{l}-0.014 \\
(0.011)\end{array}$ & $\begin{array}{l}-0.003 \\
(0.015)\end{array}$ & $\begin{array}{l}-0.022 \\
(0.119)\end{array}$ & $\begin{array}{l}-0.391 * * * \\
(0.127)\end{array}$ \\
\hline $\begin{array}{l}\alpha_{1} \begin{array}{l}\text { Negative Taxable Income } \\
\text { (NEGTI) }\end{array}\end{array}$ & $\begin{array}{l}-0.267 * * \\
(0.122)\end{array}$ & $\begin{array}{l}-0.007 \\
(0.023)\end{array}$ & $\begin{array}{l}-0.054^{*} \\
(0.027)\end{array}$ & $\begin{array}{l}-0.150 \\
(0.233)\end{array}$ & $\begin{array}{l}-0.022 \\
(0.018)\end{array}$ & $\begin{array}{l}-0.175^{* * *} \\
(0.007)\end{array}$ & $\begin{array}{l}0.056 \\
(0.038)\end{array}$ & $\begin{array}{l}0.109 \\
(0.119)\end{array}$ & $\begin{array}{l}-0.165 \\
(0.190)\end{array}$ & $\begin{array}{l}0.552 \\
(0.400)\end{array}$ \\
\hline$\beta_{1}$ ВООК63DA $>0$ & $\begin{array}{l}0.187 \\
(0.121)\end{array}$ & $\begin{array}{l}0.429 * * * \\
(0.134)\end{array}$ & $\begin{array}{l}0.604 * * * \\
(0.129)\end{array}$ & $\begin{array}{l}-1.635 \\
(1.259)\end{array}$ & $\begin{array}{l}0.724 * * * \\
(0.127)\end{array}$ & $\begin{array}{l}0.935^{* * *} \\
(0.146)\end{array}$ & $\begin{array}{l}1.167 * * * \\
(0.339)\end{array}$ & $\begin{array}{l}0.496 \\
(0.451)\end{array}$ & $\begin{array}{l}-0.127 \\
(0.980)\end{array}$ & $\begin{array}{l}11.111^{* *} \\
(4.557)\end{array}$ \\
\hline$\beta_{2}$ ВООК63DA $<0$ & $\begin{array}{l}0.560 * * * \\
(0.150)\end{array}$ & $\begin{array}{l}0.738^{*} \\
(0.442)\end{array}$ & $\begin{array}{l}0.757 * * * \\
(0.086)\end{array}$ & $\begin{array}{l}3.153^{* * *} \\
(1.014)\end{array}$ & $\begin{array}{l}1.023 * * * \\
(0.194)\end{array}$ & $\begin{array}{l}0.998^{* * *} \\
(0.135)\end{array}$ & $\begin{array}{l}0.531^{* *} \\
(0.202)\end{array}$ & $\begin{array}{l}1.019 * * * \\
(0.327)\end{array}$ & $\begin{array}{l}0.294 \\
(0.195)\end{array}$ & $\begin{array}{l}-1.500 \\
(1.314)\end{array}$ \\
\hline$\gamma_{1}$ BOOK63DA $>0 *$ NEGTI & $\begin{array}{l}1.128 * * \\
(0.468)\end{array}$ & $\begin{array}{l}0.086 \\
(0.136)\end{array}$ & $\begin{array}{l}0.849 * * * \\
(0.293)\end{array}$ & $\begin{array}{l}3.225 \\
(2.073)\end{array}$ & $\begin{array}{l}0.000 \\
(0.000)\end{array}$ & $\begin{array}{l}0.000 \\
(0.000)\end{array}$ & $\begin{array}{l}-0.539 \\
(0.435)\end{array}$ & $\begin{array}{l}0.491 \\
(0.940)\end{array}$ & $\begin{array}{l}0.141 \\
(1.170)\end{array}$ & $\begin{array}{l}-12.958 \\
(8.222)\end{array}$ \\
\hline$\gamma_{2}$ BOOK63DA $<0 *$ NEGTI & $\begin{array}{l}-2.106^{*} \\
(1.089)\end{array}$ & $\begin{array}{l}-0.178 \\
(0.480)\end{array}$ & $\begin{array}{l}-0.621^{* *} \\
(0.252)\end{array}$ & $\begin{array}{l}0.407 \\
(3.870)\end{array}$ & $\begin{array}{l}-0.474 * * \\
(0.204)\end{array}$ & $\begin{array}{l}-2.443^{* * *} \\
(0.135)\end{array}$ & $\begin{array}{l}0.750 \\
(0.679)\end{array}$ & $\begin{array}{l}0.099 \\
(0.960)\end{array}$ & $\begin{array}{l}-2.122 * \\
(1.227)\end{array}$ & $\begin{array}{l}2.963 \\
(5.380)\end{array}$ \\
\hline $\begin{array}{l}\text { Observations } \\
\text { Adjusted R-squared }\end{array}$ & $\begin{array}{l}2313 \\
0.10\end{array}$ & $\begin{array}{l}128 \\
0.36\end{array}$ & $\begin{array}{l}39 \\
0.72\end{array}$ & $\begin{array}{l}55 \\
0.26\end{array}$ & $\begin{array}{l}28 \\
0.92\end{array}$ & $\begin{array}{l}29 \\
0.83\end{array}$ & $\begin{array}{l}56 \\
0.51\end{array}$ & $\begin{array}{l}81 \\
0.25\end{array}$ & $\begin{array}{l}582 \\
0.14\end{array}$ & $\begin{array}{l}24 \\
-0.04\end{array}$ \\
\hline $\begin{array}{l}\beta_{1}+\gamma_{1} \\
\beta_{2}+\gamma_{2}\end{array}$ & $\begin{array}{l}1.315 \\
-1.546\end{array}$ & $\begin{array}{l}0.515 \\
0.560\end{array}$ & $\begin{array}{l}1.453 \\
0.136\end{array}$ & $\begin{array}{l}1.590 \\
3.560\end{array}$ & $\begin{array}{l}0.724 \\
0.549\end{array}$ & $\begin{array}{l}0.935 \\
-1.445\end{array}$ & $\begin{array}{l}0.628 \\
1.281\end{array}$ & $\begin{array}{l}0.987 \\
1.118\end{array}$ & $\begin{array}{l}0.014 \\
-1.828\end{array}$ & $\begin{array}{l}-1.847 \\
1.463\end{array}$ \\
\hline $\begin{array}{l}\text { F-tests of coefficients: } \\
\beta_{1}=\beta_{2} \\
\beta_{1}+\gamma_{1}=\beta_{2}+\gamma_{2}\end{array}$ & $\begin{array}{l}3.17 * \\
4.02 * *\end{array}$ & $\begin{array}{l}0.41 \\
0.05\end{array}$ & $\begin{array}{l}0.76 \\
8.61^{* * *}\end{array}$ & $\begin{array}{l}6.31^{* *} \\
0.15\end{array}$ & $\begin{array}{l}1.10 \\
1.51\end{array}$ & $\begin{array}{l}0.08 \\
265.83 * * *\end{array}$ & $\begin{array}{l}1.68 \\
0.52\end{array}$ & $\begin{array}{l}0.62 \\
0.01\end{array}$ & $\begin{array}{l}0.13 \\
1.14\end{array}$ & $\begin{array}{l}5.06^{* *} \\
0.08\end{array}$ \\
\hline
\end{tabular}


PANEL C: MANUfACTURING INDUSTRIES, SIC 3000 - 3999

\begin{tabular}{|c|c|c|c|c|c|c|c|c|c|c|}
\hline & $\begin{array}{l}\text { (1) } \\
\text { Rubber }\end{array}$ & $\begin{array}{l}(2) \\
\text { Leather }\end{array}$ & $\begin{array}{l}\text { (3) } \\
\text { Stone }\end{array}$ & $\begin{array}{l}(4) \\
\text { Primary } \\
\text { Metals } \\
\end{array}$ & $\begin{array}{l}\text { (5) } \\
\text { Fabricated } \\
\text { Metals } \\
\end{array}$ & $\begin{array}{l}(6) \\
\text { Industrial } \\
\text { Machinery } \\
\end{array}$ & $\begin{array}{l}\text { (7) } \\
\text { Electrical } \\
\text { Equipment } \\
\end{array}$ & $\begin{array}{l}(8) \\
\text { Transportati } \\
\text { Equipment } \\
\end{array}$ & $\begin{array}{l}\text { (9) } \\
\text { onInstruments }\end{array}$ & $\begin{array}{l}\text { (10) } \\
\text { Misc Mfg }\end{array}$ \\
\hline$\alpha_{0}$ INTERCEPT & $\begin{array}{l}-0.007 \\
(0.017)\end{array}$ & $\begin{array}{l}0.008 \\
(0.016)\end{array}$ & $\begin{array}{l}0.002 \\
(0.005)\end{array}$ & $\begin{array}{l}-0.028^{*} \\
(0.014)\end{array}$ & $\begin{array}{l}-0.005 \\
(0.007)\end{array}$ & $\begin{array}{l}-0.054 \\
(0.041)\end{array}$ & $\begin{array}{l}0.033^{* * *} \\
(0.012)\end{array}$ & $\begin{array}{l}-0.007 \\
(0.009)\end{array}$ & $\begin{array}{l}-0.093 * * \\
(0.038)\end{array}$ & $\begin{array}{l}-0.009 \\
(0.012)\end{array}$ \\
\hline $\begin{array}{ll}\alpha_{1} & \text { Negative Taxable Income } \\
& \text { (NEGTI) }\end{array}$ & $\begin{array}{l}0.024 \\
(0.027)\end{array}$ & $\begin{array}{l}-0.011 \\
(0.020)\end{array}$ & $\begin{array}{l}-0.024 * * * \\
(0.006)\end{array}$ & $\begin{array}{l}0.036 \\
(0.024)\end{array}$ & $\begin{array}{l}0.009 \\
(0.023)\end{array}$ & $\begin{array}{l}-0.177 \\
(0.151)\end{array}$ & $\begin{array}{l}-0.090 * * \\
(0.038)\end{array}$ & $\begin{array}{l}-0.025 \\
(0.037)\end{array}$ & $\begin{array}{l}-0.194 \\
(0.192)\end{array}$ & $\begin{array}{l}0.073 * * * \\
(0.027)\end{array}$ \\
\hline$\beta_{1}$ BOOK63DA $>0$ & $\begin{array}{l}0.704^{*} \\
(0.354)\end{array}$ & $\begin{array}{l}1.015^{* * *} \\
(0.142)\end{array}$ & $\begin{array}{l}0.784 * * * \\
(0.075)\end{array}$ & $\begin{array}{l}1.065^{* * * *} \\
(0.116)\end{array}$ & $\begin{array}{l}0.949 * * * \\
(0.087)\end{array}$ & $\begin{array}{l}1.265^{* * * *} \\
(0.260)\end{array}$ & $\begin{array}{l}0.075^{* *} \\
(0.031)\end{array}$ & $\begin{array}{l}0.815^{* * *} \\
(0.108)\end{array}$ & $\begin{array}{l}0.836^{* *} \\
(0.409)\end{array}$ & $\begin{array}{l}0.899 * * * \\
(0.172)\end{array}$ \\
\hline$\beta_{2}$ BOOK63DA $<0$ & $\begin{array}{l}0.733^{*} \\
(0.406)\end{array}$ & $\begin{array}{l}1.204^{* * *} \\
(0.247)\end{array}$ & $\begin{array}{l}0.989 * * * \\
(0.034)\end{array}$ & $\begin{array}{l}0.546 * * \\
(0.275)\end{array}$ & $\begin{array}{l}0.884 * * * \\
(0.142)\end{array}$ & $\begin{array}{l}-0.202 \\
(0.546)\end{array}$ & $\begin{array}{l}0.466^{* * * *} \\
(0.142)\end{array}$ & $\begin{array}{l}0.819 * * * \\
(0.104)\end{array}$ & $\begin{array}{l}0.603 * * \\
(0.306)\end{array}$ & $\begin{array}{r}0.626 * * * \\
(0.220)\end{array}$ \\
\hline$\gamma_{1}$ BOOK63DA $>0 *$ NEGTI & $\begin{array}{l}0.421 \\
(0.394)\end{array}$ & $\begin{array}{l}0.000 \\
(0.000)\end{array}$ & $\begin{array}{l}1.526 * * * \\
(0.226)\end{array}$ & $\begin{array}{l}-0.652 \\
(0.460)\end{array}$ & $\begin{array}{l}0.159 \\
(0.406)\end{array}$ & $\begin{array}{l}1.073^{* * *} \\
(0.321)\end{array}$ & $\begin{array}{l}0.899 * * * \\
(0.306)\end{array}$ & $\begin{array}{l}0.631 \\
(1.178)\end{array}$ & $\begin{array}{l}3.585^{*} \\
(1.852)\end{array}$ & $\begin{array}{l}-0.736^{*} \\
(0.393)\end{array}$ \\
\hline$\gamma_{2}$ BOOK63DA $<0 *$ NEGTI & $\begin{array}{l}0.221 \\
(0.431)\end{array}$ & $\begin{array}{l}0.000 \\
(0.000)\end{array}$ & $\begin{array}{l}-0.595 * * * \\
(0.043)\end{array}$ & $\begin{array}{l}-0.256 \\
(0.288)\end{array}$ & $\begin{array}{l}-0.159 \\
(0.334)\end{array}$ & $\begin{array}{l}0.210 \\
(0.787)\end{array}$ & $\begin{array}{l}-0.212 \\
(0.322)\end{array}$ & $\begin{array}{l}-0.521^{* * *} \\
(0.178)\end{array}$ & $\begin{array}{l}-1.172 \\
(0.840)\end{array}$ & $\begin{array}{l}0.826 * * \\
(0.325)\end{array}$ \\
\hline $\begin{array}{l}\text { Observations } \\
\text { Adjusted R-squared }\end{array}$ & $\begin{array}{l}52 \\
0.57\end{array}$ & $\begin{array}{l}13 \\
0.97\end{array}$ & $\begin{array}{l}29 \\
0.96\end{array}$ & $\begin{array}{l}108 \\
0.36\end{array}$ & $\begin{array}{l}55 \\
0.79\end{array}$ & $\begin{array}{l}226 \\
0.09\end{array}$ & $\begin{array}{l}401 \\
0.12\end{array}$ & $\begin{array}{l}83 \\
0.64\end{array}$ & $\begin{array}{l}273 \\
0.04\end{array}$ & $\begin{array}{l}51 \\
0.73\end{array}$ \\
\hline $\begin{array}{l}\beta_{1}+\gamma_{1} \\
\beta_{2}+\gamma_{2}\end{array}$ & $\begin{array}{c}1.125 \\
0.954\end{array}$ & $\begin{array}{l}1.015 \\
1.204\end{array}$ & $\begin{array}{l}2.310 \\
0.394\end{array}$ & $\begin{array}{l}0.413 \\
0.290\end{array}$ & $\begin{array}{l}1.108 \\
0.725\end{array}$ & $\begin{array}{l}2.338 \\
0.008\end{array}$ & $\begin{array}{l}0.974 \\
0.254\end{array}$ & $\begin{array}{l}1.446 \\
0.298\end{array}$ & $\begin{array}{l}4.421 \\
-0.569\end{array}$ & $\begin{array}{l}0.163 \\
1.452\end{array}$ \\
\hline $\begin{array}{l}\text { F-tests of coefficients: } \\
\beta_{1}=\beta_{2} \\
\beta_{1}+\gamma_{1}=\beta_{2}+\gamma_{2}\end{array}$ & $\begin{array}{l}0.00 \\
0.43\end{array}$ & $\begin{array}{l}0.25 \\
0.25\end{array}$ & $\begin{array}{l}4.41^{* *} \\
67.50 * * *\end{array}$ & $\begin{array}{l}2.51 \\
0.06\end{array}$ & $\begin{array}{l}0.11 \\
0.37\end{array}$ & $\begin{array}{l}4.98^{* *} \\
15.14^{* * *}\end{array}$ & $\begin{array}{l}7.01^{* * *} \\
2.65^{*}\end{array}$ & $\begin{array}{l}0.00 \\
0.84\end{array}$ & $\begin{array}{l}0.15 \\
5.34^{* *}\end{array}$ & $\begin{array}{l}0.68 \\
6.42\end{array}$ \\
\hline
\end{tabular}


Table 10

Financial Reporting Effects of Tax Discretionary Accruals, Pooled Sample

$$
\frac{D \hat{A}_{i}^{F}}{A_{i, t-1}}=\alpha_{0}+\alpha_{1}+\beta_{1}\left(\frac{D \hat{A}_{i}^{T}}{A_{i, t-1}}>0\right)+\beta_{2}\left(\frac{D \hat{A}_{i}^{T}}{A_{i, t-1}}<0\right)+\gamma_{1}\left(\frac{D \hat{A}_{i}^{T}}{A_{i, t-1}}>0 * N E G T I\right)+\gamma_{2}\left(\frac{D \hat{A}_{i}^{T}}{A_{i, t-1}}<0 * N E G T I\right)
$$

(1)

Matched Tax and

Financial Data

\begin{tabular}{|c|c|c|}
\hline$\alpha_{0}$ INTERCEPT & $\begin{array}{l}-0.015 \\
(0.017)\end{array}$ & $\begin{array}{l}0.023^{* *} \\
(0.010)\end{array}$ \\
\hline $\begin{array}{l}\alpha_{1} \text { Negative Taxable Income } \\
\text { (NEGTI) }\end{array}$ & $\begin{array}{l}0.002 \\
(0.025)\end{array}$ & $\begin{array}{l}-0.079 * * * \\
(0.016)\end{array}$ \\
\hline$\beta_{1} \mathrm{DA}^{\mathrm{T}}>0$ & $\begin{array}{l}1.247^{* * *} \\
(0.277)\end{array}$ & $\begin{array}{l}-0.124 \\
(0.082)\end{array}$ \\
\hline$\beta_{2} \mathrm{DA}^{\mathrm{T}}<0$ & $\begin{array}{l}0.571^{* * *} \\
(0.120)\end{array}$ & $\begin{array}{l}0.033 \\
(0.024)\end{array}$ \\
\hline$\gamma_{1}\left(\mathrm{DA}^{\mathrm{T}}>0\right) *$ NEGTI & $\begin{array}{l}-0.897^{* * *} \\
(0.294)\end{array}$ & $\begin{array}{l}0.994 * * * \\
(0.142)\end{array}$ \\
\hline$\gamma_{2}\left(\mathrm{DA}^{\mathrm{T}}<0\right) *$ NEGTI & $\begin{array}{l}0.066 \\
(0.230)\end{array}$ & $\begin{array}{l}0.093 \\
(0.144)\end{array}$ \\
\hline Observations & 6,062 & 5,226 \\
\hline Adjusted R-squared & 0.26 & 0.05 \\
\hline
\end{tabular}

(2)

Only

$0.023^{* *}$

(0.016)

$-0.124$

0.033

$0.994 * * *$

0.093

.144)
Financial Statement

Robust standard errors in parentheses

* significant at $10 \%$; ** significant at $5 \%$; ** significant at $1 \%$
$\beta_{1}+\gamma_{1}$
0.350
0.870
$\beta_{2}+\gamma_{2}$
0.637
0.126
F-tests of coefficients:
$\beta_{1}=\beta_{2}$
$\beta_{1}+\gamma_{1}=\beta_{2}+\gamma_{2}$
$5.37 * *$
$3.21 *$
$17.80 * * *$
$13.06^{* *}$

Variable definitions: The dependent variable is scaled discretionary financial reporting accruals. NEGTI is a binary variable equal to one if the firm has negative taxable income, zero otherwise. $\mathrm{DA}^{\mathrm{T}}$ is the amount of discretionary accruals estimated from either the tax return (LINE28DA) or imputed from the financial statement (GROSS63DA), and is separated into two variables, $\left(\mathrm{DA}^{\mathrm{T}}>0, \mathrm{DA}^{\mathrm{T}}<0\right)$ depending on the sign of the discretionary accrual. $\mathrm{DA} A^{\mathrm{T}}>0 * \mathrm{NEGTI}$ and $\mathrm{DA}^{\mathrm{T}}<0 *$ NEGTI are interaction terms of the sign of the tax discretionary accrual and tax status.

Robust standard errors in parentheses

* significant at $10 \%$; ** significant at $5 \%$; *** significant at $1 \%$ 
Table 11

Financial Reporting Effects of Tax Discretionary Accruals, Industry Results

$$
\frac{D \hat{A}_{i}^{F}}{A_{i, t-1}}=\alpha_{0}+\alpha_{1}+\beta_{1}\left(\frac{D \hat{A}_{i}^{T}}{A_{i, t-1}}>0\right)+\beta_{2}\left(\frac{D \hat{A}_{i}^{T}}{A_{i, t-1}}<0\right)+\gamma_{1}\left(\frac{D \hat{A}_{i}^{T}}{A_{i, t-1}}>0 * N E G T I\right)+\gamma_{2}\left(\frac{D \hat{A}_{i}^{T}}{A_{i, t-1}}<0 * N E G T I\right)
$$

PANEL A: NON-MANUFACTURING INDUSTRIES

\begin{tabular}{|c|c|c|c|c|c|c|c|c|c|c|}
\hline & $\begin{array}{l}(1) \\
\text { All }\end{array}$ & $\begin{array}{l}(2) \\
\text { Agric }\end{array}$ & Mineral & $\begin{array}{l}\text { Constr } \\
\text { Con }\end{array}$ & $\begin{array}{l}\text { (4) } \\
\text { RegInds }\end{array}$ & $\begin{array}{l}\text { (5) } \\
\text { Whole }\end{array}$ & $\begin{array}{l}(6) \\
\text { Retail }\end{array}$ & $\begin{array}{l}(7) \\
\text { FIRE }\end{array}$ & $\begin{array}{l}(8) \\
\text { Service }\end{array}$ & $\begin{array}{l}\text { (9)(10) } \\
\text { PubAdmin }\end{array}$ \\
\hline $\begin{array}{l}\alpha_{0} \text { INTERCEPT } \\
\end{array}$ & $\begin{array}{l}-0.022 \\
(0.023)\end{array}$ & $\begin{array}{l}0.006 \\
(0.016)\end{array}$ & $\begin{array}{l}0.034 * * \\
(0.014)\end{array}$ & $\begin{array}{l}0.006 \\
(0.007)\end{array}$ & $\begin{array}{l}0.002 \\
(0.003)\end{array}$ & $\begin{array}{l}-0.003 \\
(0.005)\end{array}$ & $\begin{array}{l}-0.004 \\
(0.005)\end{array}$ & $\begin{array}{l}-0.014^{* *} \\
(0.007)\end{array}$ & $\begin{array}{l}-0.103 \\
(0.071)\end{array}$ & $\begin{array}{l}-0.102 \\
(0.251)\end{array}$ \\
\hline $\begin{array}{l}\alpha_{1} \begin{array}{l}\text { Negative Taxable Income } \\
\text { (NEGTI) }\end{array}\end{array}$ & $\begin{array}{l}0.031 \\
(0.033)\end{array}$ & $\begin{array}{l}-0.014 \\
(0.030)\end{array}$ & $\begin{array}{l}-0.058^{* *} \\
(0.028)\end{array}$ & $\begin{array}{l}0.013 \\
(0.024)\end{array}$ & $\begin{array}{l}-0.004 \\
(0.011)\end{array}$ & $\begin{array}{l}-0.009 \\
(0.013)\end{array}$ & $\begin{array}{l}-0.002 \\
(0.019)\end{array}$ & $\begin{array}{l}-0.021 \\
(0.019)\end{array}$ & $\begin{array}{l}0.120 \\
(0.087)\end{array}$ & $\begin{array}{l}0.285 \\
(0.315)\end{array}$ \\
\hline$\beta_{1}$ LINE28DA $>0$ & $\begin{array}{l}1.445^{* * *} \\
(0.413)\end{array}$ & $\begin{array}{l}0.905^{* * *} \\
(0.056)\end{array}$ & $\begin{array}{l}0.681^{* * *} \\
(0.121)\end{array}$ & $\begin{array}{l}1.008 * * * \\
(0.052)\end{array}$ & $\begin{array}{l}0.924^{* * *} \\
(0.067)\end{array}$ & $\begin{array}{l}0.893^{* * *} \\
(0.058)\end{array}$ & $\begin{array}{l}0.965^{* * *} \\
(0.048)\end{array}$ & $\begin{array}{l}0.929 * * * \\
(0.071)\end{array}$ & $\begin{array}{l}2.697 * * * \\
(0.964)\end{array}$ & $\begin{array}{l}2.094^{* * *} \\
(0.586)\end{array}$ \\
\hline$\beta_{2}$ LINE28DA $<0$ & $\begin{array}{l}0.466 * * * \\
(0.129)\end{array}$ & $\begin{array}{l}1.828 * * * \\
(0.328)\end{array}$ & $\begin{array}{l}0.514^{*} \\
(0.273)\end{array}$ & $\begin{array}{l}0.790^{* * *} \\
(0.133)\end{array}$ & $\begin{array}{l}0.673^{* * *} \\
(0.152)\end{array}$ & $\begin{array}{l}0.772 * * * \\
(0.056)\end{array}$ & $\begin{array}{l}0.559 * * \\
(0.227)\end{array}$ & $\begin{array}{l}0.738^{* * *} \\
(0.069)\end{array}$ & $\begin{array}{l}-0.005 \\
(0.288)\end{array}$ & $\begin{array}{l}1.885 \\
(1.125)\end{array}$ \\
\hline$\gamma_{1}$ LINE28DA $>0 *$ NEGTI & $\begin{array}{l}-1.117 * * * \\
(0.432)\end{array}$ & $\begin{array}{l}2.129 * * \\
(0.873)\end{array}$ & $\begin{array}{l}0.195 \\
(0.385)\end{array}$ & $\begin{array}{l}-1.759 * * * \\
(0.583)\end{array}$ & $\begin{array}{l}-0.353 \\
(0.314)\end{array}$ & $\begin{array}{l}-0.161 \\
(0.202)\end{array}$ & $\begin{array}{l}-0.765 \\
(0.707)\end{array}$ & $\begin{array}{l}0.105 \\
(0.104)\end{array}$ & $\begin{array}{l}-2.426 * * \\
(0.972)\end{array}$ & $\begin{array}{l}-2.778^{* *} \\
(1.200)\end{array}$ \\
\hline$\gamma_{2}$ LINE28DA $<0 *$ NEGTI & $\begin{array}{l}0.533^{*} \\
(0.302)\end{array}$ & $\begin{array}{l}-0.935 * \\
(0.441)\end{array}$ & $\begin{array}{l}0.346 \\
(0.370)\end{array}$ & $\begin{array}{l}0.532 \\
(0.385)\end{array}$ & $\begin{array}{l}0.206 \\
(0.153)\end{array}$ & $\begin{array}{l}0.006 \\
(0.086)\end{array}$ & $\begin{array}{l}0.195 \\
(0.261)\end{array}$ & $\begin{array}{l}-0.127 \\
(0.178)\end{array}$ & $\begin{array}{l}1.131^{* *} \\
(0.565)\end{array}$ & $\begin{array}{l}0.000 \\
(0.000)\end{array}$ \\
\hline $\begin{array}{l}\text { Observations } \\
\text { Adjusted R-squared }\end{array}$ & $\begin{array}{l}3424 \\
0.41\end{array}$ & $\begin{array}{l}20 \\
0.93\end{array}$ & $\begin{array}{l}304 \\
0.41\end{array}$ & $\begin{array}{l}77 \\
0.79\end{array}$ & $\begin{array}{l}766 \\
0.84\end{array}$ & $\begin{array}{l}320 \\
0.87\end{array}$ & $\begin{array}{l}663 \\
0.49\end{array}$ & $\begin{array}{l}226 \\
0.79\end{array}$ & $\begin{array}{l}1028 \\
0.38\end{array}$ & $\begin{array}{l}20 \\
0.16\end{array}$ \\
\hline $\begin{array}{l}\beta_{1}+\gamma_{1} \\
\beta_{2}+\gamma_{2}\end{array}$ & $\begin{array}{c}0.328 \\
0.999\end{array}$ & $\begin{array}{l}3.034 \\
0.893\end{array}$ & $\begin{array}{l}0.876 \\
0.860\end{array}$ & $\begin{array}{l}-0.751 \\
1.322\end{array}$ & $\begin{array}{l}0.571 \\
0.879\end{array}$ & $\begin{array}{l}0.732 \\
0.778\end{array}$ & $\begin{array}{l}0.200 \\
0.754\end{array}$ & $\begin{array}{l}1.034 \\
0.611\end{array}$ & $\begin{array}{l}0.271 \\
1.126\end{array}$ & $\begin{array}{l}-0.684 \\
1.885\end{array}$ \\
\hline $\begin{array}{l}\text { F-tests of coefficients: } \\
\beta_{1}=\beta_{2} \\
\beta_{1}+\gamma_{1}=\beta_{2}+\gamma_{2}\end{array}$ & $\begin{array}{l}3.41^{*} \\
4.41^{* *}\end{array}$ & $\begin{array}{l}5.80^{* *} \\
3.45^{*}\end{array}$ & $\begin{array}{l}0.24 \\
0.00\end{array}$ & $\begin{array}{l}1.98 \\
6.11^{* *}\end{array}$ & $\begin{array}{l}2.02 \\
0.98\end{array}$ & $\begin{array}{l}1.82 \\
0.05\end{array}$ & $\begin{array}{l}2.40 \\
0.49\end{array}$ & $\begin{array}{l}2.99 * \\
4.58^{* *}\end{array}$ & $\begin{array}{l}4.82 * * \\
2.60\end{array}$ & $\begin{array}{l}0.03 \\
2.23\end{array}$ \\
\hline
\end{tabular}


PANEL B: MANUFACTURING INDUSTRIES, SIC 2000 - 2999

\begin{tabular}{|c|c|c|c|c|c|c|c|c|c|c|}
\hline & (1) & (2) & (3) & (4) & (5) & (6) & (7) & (8) & (9) & (10) \\
\hline & All & Food & Textile & Apparel & Lumber & Furniture & Paper & Printing & Chemicals & Petroleum \\
\hline$\alpha_{0}$ INTERCEPT & $\begin{array}{l}0.004 \\
(0.006)\end{array}$ & $\begin{array}{l}-0.016^{* *} \\
(0.008)\end{array}$ & $\begin{array}{l}-0.005 \\
(0.007)\end{array}$ & $\begin{array}{l}0.005 \\
(0.006)\end{array}$ & $\begin{array}{l}-0.021^{* *} \\
(0.009)\end{array}$ & $\begin{array}{l}-0.003 \\
(0.007)\end{array}$ & $\begin{array}{l}-0.016 \\
(0.022)\end{array}$ & $\begin{array}{l}0.001 \\
(0.005)\end{array}$ & $\begin{array}{l}0.092 * * * \\
(0.020)\end{array}$ & $\begin{array}{l}0.037^{* *} \\
(0.014)\end{array}$ \\
\hline $\begin{array}{l}\alpha_{1} \begin{array}{l}\text { Negative Taxable Income } \\
\text { (NEGTI) }\end{array}\end{array}$ & $\begin{array}{l}-0.048 * * * \\
(0.017)\end{array}$ & $\begin{array}{l}-0.098^{* * *} \\
(0.028)\end{array}$ & $\begin{array}{l}0.017 \\
(0.015)\end{array}$ & $\begin{array}{l}0.001 \\
(0.027)\end{array}$ & $\begin{array}{l}0.230 * * * \\
(0.025)\end{array}$ & $\begin{array}{l}-0.083 \\
(0.077)\end{array}$ & $\begin{array}{l}-0.017 \\
(0.041)\end{array}$ & $\begin{array}{l}-0.085^{* * *} \\
(0.031)\end{array}$ & $\begin{array}{l}-0.114 * * * \\
(0.038)\end{array}$ & $\begin{array}{l}-0.063 \\
(0.037)\end{array}$ \\
\hline$\beta_{1}$ LINE28DA>0 & $\begin{array}{l}0.887 * * * \\
(0.110)\end{array}$ & $\begin{array}{l}1.057^{* * *} \\
(0.130)\end{array}$ & $\begin{array}{l}1.050^{* * *} \\
(0.148)\end{array}$ & $\begin{array}{l}0.833 * * * \\
(0.042)\end{array}$ & $\begin{array}{l}1.425^{* * *} \\
(0.160)\end{array}$ & $\begin{array}{l}0.851^{* * *} \\
(0.129)\end{array}$ & $\begin{array}{l}1.194 * * * \\
(0.433)\end{array}$ & $\begin{array}{l}0.867 * * * \\
(0.068)\end{array}$ & $\begin{array}{l}0.471^{* * *} \\
(0.122)\end{array}$ & $\begin{array}{l}0.397 * * * \\
(0.130)\end{array}$ \\
\hline$\beta_{2}$ LINE28DA $<0$ & $\begin{array}{l}0.827 * * * \\
(0.199)\end{array}$ & $\begin{array}{l}0.947^{* * *} \\
(0.142)\end{array}$ & $\begin{array}{l}0.957 * * * \\
(0.060)\end{array}$ & $\begin{array}{l}1.106^{* * *} \\
(0.111)\end{array}$ & $\begin{array}{l}0.207 \\
(0.195)\end{array}$ & $\begin{array}{l}0.617 * * * \\
(0.184)\end{array}$ & $\begin{array}{l}0.258 \\
(0.383)\end{array}$ & $\begin{array}{l}1.105^{* * *} \\
(0.055)\end{array}$ & $\begin{array}{l}1.512^{* * *} \\
(0.494)\end{array}$ & $\begin{array}{l}1.321^{* * *} \\
(0.398)\end{array}$ \\
\hline$\gamma_{1}$ LINE28DA $>0 *$ NEGTI & $\begin{array}{l}-0.479 * * * \\
(0.180)\end{array}$ & $\begin{array}{l}0.407 \\
(0.769)\end{array}$ & $\begin{array}{l}-0.216 \\
(0.301)\end{array}$ & $\begin{array}{l}-0.071 \\
(0.117)\end{array}$ & $\begin{array}{l}0.000 \\
(0.000)\end{array}$ & $\begin{array}{l}0.781 \\
(0.783)\end{array}$ & $\begin{array}{l}0.132 \\
(1.071)\end{array}$ & $\begin{array}{l}-0.588 \\
(0.806)\end{array}$ & $\begin{array}{l}-0.211 \\
(0.184)\end{array}$ & $\begin{array}{l}-0.559 \\
(0.393)\end{array}$ \\
\hline$\gamma_{2}$ LINE28DA $<0 *$ NEGTI & $\begin{array}{l}-0.594^{* * *} \\
(0.219)\end{array}$ & $\begin{array}{l}-0.924^{* * *} \\
(0.169)\end{array}$ & $\begin{array}{l}0.124 \\
(0.146)\end{array}$ & $\begin{array}{l}-0.336 * * \\
(0.157)\end{array}$ & $\begin{array}{l}4.045^{* * *} \\
(0.309)\end{array}$ & $\begin{array}{l}-0.421 \\
(0.936)\end{array}$ & $\begin{array}{l}0.417 \\
(0.580)\end{array}$ & $\begin{array}{l}-1.444^{* * *} \\
(0.119)\end{array}$ & $\begin{array}{l}-1.292^{* *} \\
(0.510)\end{array}$ & $\begin{array}{l}-1.485^{* *} \\
(0.666)\end{array}$ \\
\hline Observations & 2638 & 170 & 44 & 55 & 31 & 32 & 68 & 96 & 630 & 32 \\
\hline Adjusted R-squared & 0.13 & 0.49 & 0.85 & 0.92 & 0.87 & 0.77 & 0.24 & 0.59 & 0.04 & 0.33 \\
\hline $\begin{array}{l}\beta_{1}+\gamma_{1} \\
\beta_{2}+\gamma_{2}\end{array}$ & $\begin{array}{l}0.408 \\
0.233\end{array}$ & $\begin{array}{l}1.464 \\
0.023\end{array}$ & $\begin{array}{l}0.834 \\
1.081\end{array}$ & $\begin{array}{l}0.762 \\
0.770\end{array}$ & $\begin{array}{l}1.425 \\
4.252\end{array}$ & $\begin{array}{l}1.632 \\
0.196\end{array}$ & $\begin{array}{l}1.326 \\
0.675\end{array}$ & $\begin{array}{l}0.279 \\
-0.339\end{array}$ & $\begin{array}{l}0.260 \\
0.220\end{array}$ & $\begin{array}{l}-0.162 \\
-0.164\end{array}$ \\
\hline $\begin{array}{l}\text { F-tests of coefficients: } \\
\beta_{1}=\beta_{2} \\
\beta_{1}+\gamma_{1}=\beta_{2}+\gamma_{2}\end{array}$ & $\begin{array}{l}0.06 \\
0.89\end{array}$ & $\begin{array}{l}0.25 \\
3.46^{*}\end{array}$ & $\begin{array}{l}0.28 \\
0.48\end{array}$ & $\begin{array}{l}4.33^{* *} \\
0.00\end{array}$ & $\begin{array}{l}15.54 * * * \\
96.43^{* * *}\end{array}$ & $\begin{array}{l}0.79 \\
0.72\end{array}$ & $\begin{array}{l}1.71 \\
0.32\end{array}$ & $\begin{array}{l}6.07 * * \\
0.55\end{array}$ & $\begin{array}{l}3.62 * * * \\
0.03\end{array}$ & $\begin{array}{l}3.34^{*} \\
0.00\end{array}$ \\
\hline
\end{tabular}


PANEL C: MANUFACTURING INDUSTRIES, SIC 3000 - 3999

\begin{tabular}{|c|c|c|c|c|c|c|c|c|c|c|}
\hline & $\begin{array}{l}(1) \\
\text { Rubber }\end{array}$ & $\begin{array}{l}\text { (2) } \\
\text { Leather }\end{array}$ & $\begin{array}{l}\text { (3) } \\
\text { Stone }\end{array}$ & $\begin{array}{l}\text { (4) } \\
\text { Primary } \\
\text { Metals } \\
\end{array}$ & $\begin{array}{l}\text { (5) } \\
\text { Fabricated } \\
\text { Metals } \\
\end{array}$ & $\begin{array}{l}\text { (6) } \\
\text { Industrial } \\
\text { Machinery } \\
\end{array}$ & $\begin{array}{l}\text { (7) } \\
\text { Electrical } \\
\text { Equipment } \\
\end{array}$ & $\begin{array}{l}(8) \\
\text { Transportatioı } \\
\text { Equipment } \\
\end{array}$ & $\begin{array}{l}\text { (9) } \\
\text { Instruments }\end{array}$ & $\begin{array}{l}\text { (10) } \\
\text { Misc Mfg }\end{array}$ \\
\hline$\alpha_{0}$ INTERCEPT & $\begin{array}{l}0.009 \\
(0.007)\end{array}$ & $\begin{array}{l}0.034 \\
(0.030)\end{array}$ & $\begin{array}{l}0.005 \\
(0.005)\end{array}$ & $\begin{array}{l}-0.005 \\
(0.007)\end{array}$ & $\begin{array}{l}0.003 \\
(0.004)\end{array}$ & $\begin{array}{l}-0.009 \\
(0.014)\end{array}$ & $\begin{array}{l}-0.033 \\
(0.031)\end{array}$ & $\begin{array}{l}0.011^{*} \\
(0.006)\end{array}$ & $\begin{array}{l}0.030^{* *} \\
(0.012)\end{array}$ & $\begin{array}{l}-0.001 \\
(0.009)\end{array}$ \\
\hline $\begin{array}{l}\alpha_{1} \text { Negative Taxable Income } \\
\text { (NEGTI) }\end{array}$ & $\begin{array}{l}-0.013 \\
(0.012)\end{array}$ & $\begin{array}{l}-0.132 * * \\
(0.042)\end{array}$ & $\begin{array}{l}-0.055^{*} \\
(0.030)\end{array}$ & $\begin{array}{l}0.012 \\
(0.013)\end{array}$ & $\begin{array}{l}-0.013 \\
(0.024)\end{array}$ & $\begin{array}{l}-0.071^{* * *} \\
(0.027)\end{array}$ & $\begin{array}{l}-0.024 \\
(0.040)\end{array}$ & $\begin{array}{l}-0.032 * \\
(0.017)\end{array}$ & $\begin{array}{l}-0.069 * * \\
(0.027)\end{array}$ & $\begin{array}{l}-0.009 \\
(0.026)\end{array}$ \\
\hline$\beta_{1}$ LINE28DA $>0$ & $\begin{array}{l}0.667 * * * \\
(0.100)\end{array}$ & $\begin{array}{l}-0.669 * \\
(0.331)\end{array}$ & $\begin{array}{l}0.801 * * * \\
(0.046)\end{array}$ & $\begin{array}{l}1.084 * * * \\
(0.071)\end{array}$ & $\begin{array}{l}0.928 * * * \\
(0.050)\end{array}$ & $\begin{array}{l}0.926 * * * \\
(0.104)\end{array}$ & $\begin{array}{l}1.484^{* *} \\
(0.618)\end{array}$ & $\begin{array}{l}0.885^{* * *} \\
(0.048)\end{array}$ & $\begin{array}{l}0.634 * * * \\
(0.142)\end{array}$ & $\begin{array}{l}0.915^{* * *} \\
(0.109)\end{array}$ \\
\hline$\beta_{2}$ LINE28DA $<0$ & $\begin{array}{l}0.946^{* * *} \\
(0.118)\end{array}$ & $\begin{array}{l}0.051 \\
(0.430)\end{array}$ & $\begin{array}{l}1.078 * * * \\
(0.116)\end{array}$ & $\begin{array}{l}0.857 * * * \\
(0.145)\end{array}$ & $\begin{array}{l}1.045^{* * *} \\
(0.090)\end{array}$ & $\begin{array}{l}0.077 \\
(0.158)\end{array}$ & $\begin{array}{l}0.801 * \\
(0.461)\end{array}$ & $\begin{array}{l}1.099 * * * \\
(0.096)\end{array}$ & $\begin{array}{l}0.933^{* * *} \\
(0.144)\end{array}$ & $\begin{array}{l}0.708^{* * *} \\
(0.146)\end{array}$ \\
\hline$\gamma_{1}$ LINE28DA $>0 *$ NEGTI & $\begin{array}{l}0.360^{* *} \\
(0.179)\end{array}$ & $\begin{array}{l}0.000 \\
(0.000)\end{array}$ & $\begin{array}{l}0.775 \\
(1.058)\end{array}$ & $\begin{array}{l}-1.091^{* *} \\
(0.432)\end{array}$ & $\begin{array}{l}4.431 * \\
(2.593)\end{array}$ & $\begin{array}{l}0.068 \\
(0.114)\end{array}$ & $\begin{array}{l}-1.155^{*} \\
(0.676)\end{array}$ & $\begin{array}{l}-0.596^{* * *} \\
(0.218)\end{array}$ & $\begin{array}{l}-0.238 \\
(0.224)\end{array}$ & $\begin{array}{l}-0.245 \\
(0.349)\end{array}$ \\
\hline$\gamma_{2}$ LINE28DA $<0 *$ NEGTI & $\begin{array}{l}-0.099 \\
(0.147)\end{array}$ & $\begin{array}{l}0.000 \\
(0.000)\end{array}$ & $\begin{array}{l}-0.983^{* *} \\
(0.362)\end{array}$ & $\begin{array}{l}0.084 \\
(0.308)\end{array}$ & $\begin{array}{l}-0.176 \\
(0.231)\end{array}$ & $\begin{array}{l}0.421 * \\
(0.237)\end{array}$ & $\begin{array}{l}-0.638 \\
(0.487)\end{array}$ & $\begin{array}{l}-0.241 * \\
(0.129)\end{array}$ & $\begin{array}{l}-0.749 * * * \\
(0.164)\end{array}$ & $\begin{array}{l}0.118 \\
(0.211)\end{array}$ \\
\hline $\begin{array}{l}\text { Observations } \\
\text { Adjusted R-squared }\end{array}$ & $\begin{array}{l}63 \\
0.84\end{array}$ & $\begin{array}{l}13 \\
0.10\end{array}$ & $\begin{array}{l}37 \\
0.85\end{array}$ & $\begin{array}{l}139 \\
0.68\end{array}$ & $\begin{array}{l}74 \\
0.89\end{array}$ & $\begin{array}{l}254 \\
0.69\end{array}$ & $\begin{array}{l}443 \\
0.19\end{array}$ & $\begin{array}{l}103 \\
0.87\end{array}$ & $\begin{array}{l}296 \\
0.11\end{array}$ & $\begin{array}{l}58 \\
0.75\end{array}$ \\
\hline $\begin{array}{l}\beta_{1}+\gamma_{1} \\
\beta_{2}+\gamma_{2}\end{array}$ & $\begin{array}{c}1.027 \\
0.847\end{array}$ & $\begin{array}{l}-0.669 \\
0.051\end{array}$ & $\begin{array}{l}1.576 \\
0.095\end{array}$ & $\begin{array}{l}-0.007 \\
0.941\end{array}$ & $\begin{array}{l}5.359 \\
0.869\end{array}$ & $\begin{array}{l}0.994 \\
0.498\end{array}$ & $\begin{array}{l}0.329 \\
0.163\end{array}$ & $\begin{array}{l}0.289 \\
0.858\end{array}$ & $\begin{array}{l}0.396 \\
0.184\end{array}$ & $\begin{array}{l}0.670 \\
0.826\end{array}$ \\
\hline $\begin{array}{l}\text { F-tests of coefficients: } \\
\beta_{1}=\beta_{2} \\
\beta_{1}+\gamma_{1}=\beta_{2}+\gamma_{2}\end{array}$ & $\begin{array}{l}2.54 \\
0.96\end{array}$ & $\begin{array}{l}1.48 \\
1.48\end{array}$ & $\begin{array}{l}4.42^{* *} \\
1.23\end{array}$ & $\begin{array}{l}1.41 \\
2.76^{*}\end{array}$ & $\begin{array}{l}1.08 \\
2.62\end{array}$ & $\begin{array}{l}17.39 * * * \\
5.94 * *\end{array}$ & $\begin{array}{l}0.58 \\
0.25\end{array}$ & $\begin{array}{l}3.18^{*} \\
4.16^{* *}\end{array}$ & $\begin{array}{l}1.49 \\
1.15\end{array}$ & $\begin{array}{l}0.96 \\
0.12\end{array}$ \\
\hline
\end{tabular}

Robust standard errors in parentheses

* significant at $10 \%$; ** significant at $5 \%$; *** significant at $1 \%$

See Table 10 for a description of the variables. 